\title{
Small Molecule-Assisted PET: Approaches to Imaging of Conformational Diseases of the Brain
}

\section{Margit Pissarek}

Institute of Neuroscience and Medicine, INM5-Nuclear Chemistry, Forschungszentrum Jülich GmbH, Jülich, Germany

Email: m.pissarek@fz-juelich.de

How to cite this paper: Pissarek, M. (2017) Small Molecule-Assisted PET: Approaches to Imaging of Conformational Diseases of the Brain. World Journal of Neuroscience, 7, 106-139.

https://doi.org/10.4236/wjns.2017.71010

Received: December 5, 2016

Accepted: February 6, 2017

Published: February 9, 2017

Copyright $\odot 2017$ by author and Scientific Research Publishing Inc. This work is licensed under the Creative Commons Attribution International License (CC BY 4.0).

http://creativecommons.org/licenses/by/4.0/

\begin{abstract}
PET (positron emission tomography) in vivo imaging of cerebral conformational diseases is essentially based on non-peptide small molecule ligands used to detect early alterations in peptide secondary structures and subsequent accumulation of aberrant oligomers and protein deposits involved in progressive neurodegeneration, cognitive and movement disorders. In this article, an overview is given about tracers currently available and lead structures of potential PET probes for detection of $\beta$-amyloid (Aß), tau protein, $\alpha$-synuclein, constitutive $\left(\mathrm{PrP}^{\mathrm{c}}\right)$ and infectious isoforms $\left(\mathrm{PrP}^{\mathrm{sc}}\right)$ of prions (proteinaceous infectious particles) as imaging targets. Whereas the styrylpyridine derivative florbetapir, approved for clinical applications, the stilbene derivative florbetaben and the benzoxazole derivative BF227 show high affinity binding to A 3 , preclinical investigations promise improved pharmacokinetics for benzoimidazothiazoles, aryloxazoles and benzofuran derivatives. Tau protein imaging based clinically, presently, on the pyridine-pyridoindole T807 has got new incentives following identification of a series of pyrrolopyridine quinolines and pharmacokinetic improvements of fluoropropoxy quinolines including for instance THK-5351. The pyridine isoquinoline MK6240 is involved now in clinical trials. Most forward-looking efforts apply to small molecule ligands of $\alpha$-synuclein, which are expected to permit a breakthrough in differential diagnostics of Parkinson-related dementia and Lewy body diseases. However, at the moment the proposed lead structures are in affinity and blood brain barrier delivery properties below the possibilities of $A ß$ and tau protein ligands. This is the case also for potential tracers of prion proteins.
\end{abstract}

\section{Keywords}

Conformational Diseases, PET, Small Molecule Ligands, Brain, Tau Protein, $\alpha$-Synuclein, $\operatorname{PrP}$ 


\section{Introduction}

The idea to collect diverse disorders associated with the deposition of aberrant proteins under the term conformational diseases is broadly supported by multiple lines of evidence [1]-[8].

Currently, there is no doubt aberrant secondary structures of proteins typically observable during the early stage of many neurodegenerative diseases can adopt at least each other protein [9]-[15]. Alone, forty-some kinds of misfolded proteins are regarded as potentially or definitively involved in the pathogenesis of neurodegenerative diseases [4] [16] [17] [18] [19].

ß-amyloid (Aß), tau-protein, $\alpha$-synuclein and the isoforms of prions (proteinaceous infectious particles) attracted central attention in efforts to develop therapeutics and also to synthesize and to label tracers suitable for diagnostic positron emission tomography (PET) imaging in diseases with severe cognitive and movement disturbances [17]-[23].

Pre-requisition for the occurrence of aberrant protein aggregates or amylomes [22] [24] [25] is the presence of amino acid sequences able to act as "steric zippers" [16] [19] [20]—self-complementary $ß$-sheets, which serve as spine of fibrillar structures. These can enable the proteins to act as a seed forcing naïve proteins into the same conformation and to start a self-propagating chain, which supports occurrence of protein aggregates [14] [26] [27].

A cascade of events with release of oxidative species as well as activation of microglia and astrocytes [28], is suggested to result in progressive amplification of neuronal and synaptic injuries. Changes in the environment, destabilizing mutations, high concentration of proteins as well as malfunction of proteasomes can abet such transformations [22] [29]. Bioenergetic thresholds for the occurrence of misfolding have been described for short peptides [22] [30].

Clinically, cognitive degradation has been revealed as the common symptomatology of conformational diseases in the brain as well as parallelism of sporadic and familial mode of the disorders [3] [31] [32].

The role of $\beta$-sheet-induced functional alterations has been described primarily in serpins, especially, for the protein inhibitor $\alpha_{1}$-antitrypsin, a well accessible blood compound [6] [7] [13].

In Alzheimer's disease (AD), a process of shedding of ecto-domains of amyloid precursor protein (APP) supplies the seeding peptides, which are prerequsition for the formation of aggregates and senile plaques [33].

Depletion of the constitutive isoform of prions $\left(\mathrm{PrP}^{\mathrm{c}}\right)$ could prevent an increase of its infectious isoform ( $\left.\mathrm{PrP}^{\mathrm{sc}}\right)$ in mice [34] [35].

However, an initial trigger common in all conformational diseases could not be identified to date. In fact, the spectrum of possible inductors of such diseases is broad. Protein aggregates and their pre-stages are ranging rather in the middle of different pathways.

Most of them gain a toxic function on the nervous system [36].

Already early, a viral or microbial pathogenesis of $\mathrm{AD}$ had been discussed based on observations by Braak et al. [37] [38] [39] on dynamics of cerebral 
neurodegeneration [40] [41] [42] [43]. Currently, a reload of microbial-trigger hypothesis has been started by the group around Itzhaki with a resume of multiple evidence for microbial contribution in triggering conformational and neurodegenerative diseases [43] [44] [45].

Few physiological functions are presumed for APP [37] [38], Aß and $\operatorname{PrP}^{\mathrm{C}}$. In pituitary, a role of $A ß$ is suggested as a storage structure for peptide hormones [46]. Moreover, some bacteria have been shown to release amyloid into the extracellular room [40] [41] [47] [48].

Prion diseases are, undoubtedly, of infectious origin [12]. However, different strains result in different degrees of neurodegeneration and also the animal species affected decides on the vulnerability against the prion strains. $\operatorname{PrP}^{\mathrm{c}}$ is presumed to be associated with protection against divalent metal ions.

For tau protein a fundamental role in assembling of microtubuli is known [11]. $\alpha$-Synuclein is called the chameleon among these proteins because of the multitude of potential functions identified, which include neurotoxic as well as neuroprotective actions [8].

Moreover, several proteins with high propensity to misfolding e.g. aberrant tau proteins, TAR DNA binding protein 43 (TDP-43) and superoxide dismutase have been identified even in only one neurodegenerative disease like amyotrophic lateral sclerosis [14]. Another phenomenon accompanying degenerative alterations is the development of gliosis or the presence of activated microglia in the neighborhood of protein aggregates [49]. Amyloid as well as viral or microbial species and mutant enzymes, typical in neurodegenerative diseases (e.g. superoxide dismutase in amyotrophic lateral sclerosis), have been presumed to induce pro-inflammatory microglial response mediated by toll-like receptors (TLR) with a special role of TLR 2 and 4 [50] [51]. Another approach supplementing the view on the pathogenesis of $\mathrm{AD}$ and similar degenerative disorders is the mitochondrial-cascade-hypothesis [52] [53]. According to this, inherited factors defining a baseline mitochondrial function show chronological alterations and provide pre-requisitions for the induction of the amyloid cascade in late-onset $\mathrm{AD}$.

A detrimental role of $A ß$ is postulated also in the pathology of circulatory and metabolic diseases like atherosclerosis [54] [55] or diabetes. Such disease-overlapping influences are proposed also for other aberrant proteins i.e. the hyper-phosphorylated tau protein [56].

The view on the role of misfolded proteins in the CNS is changing. For example, the micro-tubulin-regulator tau protein was initially observed to be co-expressed intracellularly with extracellular amyloid in $\mathrm{AD}$ and for that reason regarded rather as a concomitant factor in this disorder. Meanwhile, it is broad agreement tau protein fibrils can occur also without amyloid in special kinds of dementia [12] and, in turn, $\alpha$-synuclein is observed in mixture with amyloid or tau protein in different neurodegenerative diseases [57].

The toxicity of misfolded proteins typical for neurodegenerative diseases, currently, is ascribed to oligomeric pre-stages of aberrant protein aggregates [9] 
[58] [59] [60]. These oligomers contain less than 10 to 50 monomers while fibrils are composed of thousands of polypeptide chains [58].

Several mechanisms of toxicity are postulated, which include chronic inflammation, proteasome failure, autophagic deregulation or transcriptional derangement [59]. Each of them could contribute also to amplification of neurotoxic actions in neurodegenerative diseases.

However, most favored toxicological mechanism arises from the biophysical concept of direct interactions between oligomeric aberrant proteins and cell membranes, which can influence membrane permeability, function of receptors, ion channels, adhesion molecules and integrins. As hypothesized by Cecchi \& Stefani [61], best conditions for such interactions are provided by membranes poor of cholesterol.

Therapeutic approaches focusing on resolution of the final protein aggregates are increasingly replaced by other ideas, which envision structures upstream to occurrence of senile plaques as for instance secretases and related proteins. Recently, also vaccination as well as multi-targeting compounds promise therapeutic progress and potential success [58] [62] [63] [64].

Presently, the tendency to separate therapeutic and diagnostic line of drug development is displaced by another trend summarized under the term theranostics [65] [66] [67]. Small molecules with new therapeutic targets at several control points of the cascade model are connected with antibodies as tool for better targeting and diagnostics of neurodegenerative alterations.

The present study regards the current spectrum of small molecules available as potential ligands of marker proteins of neurodegenerative diseases and potentially suitable for brain imaging of protein plaques and their oligomeric prestages with focus on PET probe. Up to date, most intensively investigated ligands are targeting $\mathrm{A} \beta$, tau protein, $\alpha$-synuclein, $\operatorname{PrP}^{\mathrm{c}}$ and $\mathrm{PrP}^{\mathrm{sc}}$ [57] [58] [68] [69].

\section{PET-Tracers and Their Target Structures in Neurodegenerative Diseases}

\section{1. ß-Amyloid}

\subsection{1. ß-Amyloid Peptides, Oligomerization and Clinical Importance}

Amyloid is regarded as the key biomarker of $\mathrm{AD}$ since almost 90 years. As $\mathrm{AD}$ counts for $50 \%-70 \%$ of all patients with the diagnosis dementia [70], research on this disease is the bulk contribution also to amyloid research. The predominant marker protein is $A_{\beta}$, a peptide of 40 or 42 amino acid residues (a.a.r.), which occurs after cleavage of transmembrane, receptor-like amyloid precursor protein (APP) by $\gamma$ - and $B$-secretases [71]. Constituents of these enzymes, like presenilins, nicastrin, presinilin enhancer 2 and anterior pharynx defective 1 [72] are regarded also as potential therapeutic targets in prevention of formation of amyloid fibrils, currently. Malfunction of the secretases can result in preferred release of $A_{B} 1$ - 42 [33]. The 42 a.a.r $A ß$ peptide is more hydrophobic than the 40 a.a.r. peptide and shows a higher tendency to assemble into oligomers [33]. The general process of fibril formation with shedding of ecto-domains of $A B$ 
preceding the assembly of oligomers and the final occurrence of extracellular amyloid aggregates is regarded recently as a cascade of degradation events (regulated intramembrane proteolysis; RIP) [31] [32] [33]. One of the first steps of this cascade is the increase of $A ß$ (42) peptide levels, or of the $A ß$ (42/Aß (40) ratio. Subsequent oligomerization of the $A B(42)$ peptides provokes disturbances of synaptic function and inflammatory response involving activation of microglia and astrocytes. Progression of synaptic and neuronal injury, disturbance of homeostasis as well as aberrant oligomerization and hyperphosphorylation of tau protein result in a further level of general neurological dysfunction and, finally, in cell death [32] [33]. Altogether, a slowly developing symptomatology has been described, which is passing several steps of amplification of neuronal injury [32] [73] [74]. Additionally, alterations in APO E genotype can enhance the probability of the development of a dominant variety of $\mathrm{AD}$ [74] and influences the distribution of amyloid plaques in the brain [19] [75].

The coexistence of Aß with $\alpha$-synuclein or tau protein in some kinds of dementia places special demands if PET investigations shall answer questions of differential diagnostics [57]. Deposition of aberrant proteins can start to occur already in the age of 30 and is reported to be associated in $19.5 \%$ of people younger than 75 years with mild cognitive impairment. This percentage increases to $29 \%$ in people of 85 years and older [76]. However, most of these disturbances are proceeding without impairment in the daily life. In a small fraction of people (12\%), an AD occurs within 6 years [76]. The early identification of such converters would be a task in which PET diagnostics can be useful for an early start of therapeutic interventions.

\subsubsection{A $\beta$ Ligands Suitable for PET In Vivo Imaging}

Congo red (CR) [Figure 1, (1)] due to its birefringence suitable for imaging of $A ß$ amyloid microscopically with cross polarized light was one of the first dyes used in diagnostics of $\mathrm{AD}$ [77] [78] [79] [80].

$\mathrm{CR}$, employed originally as dye in the textile industry was applied in continuously improved histological methods for in vitro labelling of Aß [80] [81] [82] but is known today as a rather unspecific ligand. As in vivo approach to amyloid diagnostics has been established also the determination of amyloid directly in the cerebrospinal fluid [82]. However, this method does not supply information on the spatial distribution of $A B$ in the brain.

CR was regarded as the standard label of amyloid in histological sections whereas the absolute arbiter for the presence of amyloid is electron microscopy [83] [84].

From the therapeutic point of view CR belongs to the small molecules expected to contribute to prevention of aggregate formation acting as chemical chaperons [18]. Detailed information on the docking sites of CR at amyloid was obtained only during the last years of amyloid research [85] [86]. Currently, there are different approaches to its binding mode. One of these is an action in detergent-like manner based on the ability of CR to create micelles if applied in concentrations $>5 \mu \mathrm{M}$ [85] [86]. The authors postulate that the formation of 


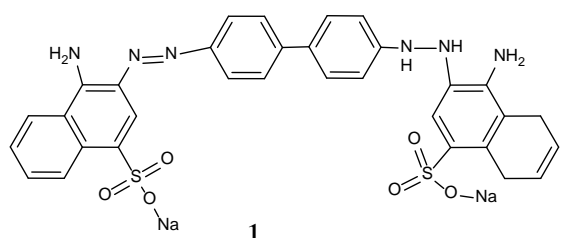<smiles>COc1cc(/C=C(/CC(=O)/C=C/c2ccc(O)c(OC)c2)c2ccc(O)c(O)c2)ccc1O</smiles><smiles>COc1cc(C=Cc2cc(CCc3ccc(O)c(OC)c3)n(CC(=O)NCc3cn(CCOCCOCCF)nn3)n2)ccc1O</smiles><smiles>C#[N+]C([N+]#C)=C(C)c1ccc2cc(N(C)CC[18F])ccc2c1</smiles><smiles>CNC1C=CC(c2nc3ccc(O)cc3s2)=CC1</smiles><smiles>CNc1ccc(-c2nc3ccc(O)cc3s2)cc1F</smiles>

5<smiles>CNc1ccc(C2Nc3ccc(O)cc3S2)cn1</smiles>

7<smiles>CNc1ccc(-c2nc3ccc(OCCC[18F])cc3s2)cc1</smiles><smiles>CCNc1ccc(/C=C/c2ccc(O)cc2)cc1</smiles>

10

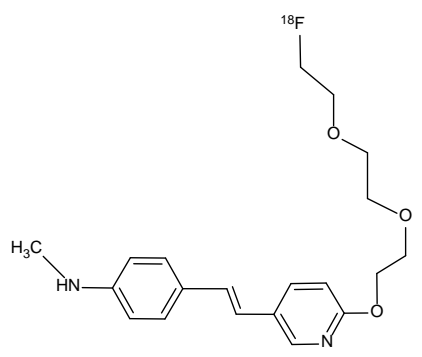

11

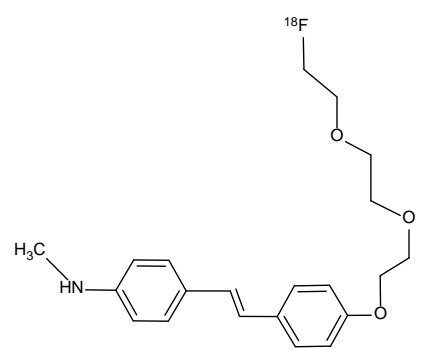

12

Figure 1. Aß ligands: 1 Disodium -4-amino-3-[4-[4-(1-amino-4-sulfonato-naphthalen-2yl)diazenylphenyl] phenyl] diazenyl-naphthalene-1-sulfonate; 2 (1E,6E)-1,7-bis(4-hydroxy-3-methoxyphenyl)hepta-1,6-diene-3,5-dione; 3 2-(3,5-bis((E)-4-hydroxy-3-methoxystyryl)-1H-pyrazol-1-yl)-N-((1-(2-(2-(2-fluoroethoxy) ethoxy) ethyl)-1H-1,2,3-triazol-4-yl)methyl)acetamide; 4 6-(1,1-diisocyanoprop-1-en-2-yl)-N-(2-(fluoro- $\left.{ }^{18} \mathrm{~F}\right)$ ethyl)$\mathrm{N}$-methylnaphthalen-2-amine; 5 2-(4-(methylamino)cyclohexa-1,5-dien-1-yl) benzo[d] thiazol-6-ol; 6 2-(3-(fluoro- $\left.{ }^{18} \mathrm{~F}\right)$-4-(methylamino)phenyl)benzo[d]thiazol-6-ol; 7 2-(6((methyl- $\left.{ }^{11} \mathrm{C}\right)$ amino) pyridin-3-yl)-2,3-dihydrobenzo[d]thiazol-6-ol; 8 4-(benzo[d]thiazol2-yl)-3-(2-fluoro- ${ }^{18} \mathrm{~F}$-ethoxy) aniline; 9 4-(6-(2-fluoro- ${ }^{18} \mathrm{~F}$-ethoxy)benzo[d] thiazol-2-yl)-Nmethyl aniline; 10 (E)-4-(4-((methyl- $\left.{ }^{11} \mathrm{C}\right)$ amino)styryl- $\left.{ }^{-11} \mathrm{C}\right)$ phenol; 11 (E)-4-(2-(6-(2-(2-(2(fluoro- $\left.{ }^{18} \mathrm{~F}\right)$ ethoxy)ethoxy)ethoxy)pyridin-3-yl)vinyl)-N-methylaniline; 12 (E)-4-(4-(2-(2(2-(fluoro- ${ }^{18} \mathrm{~F}$ )ethoxy)ethoxy)ethoxy)styryl)-N-methylaniline. ChemDraw (http://www.cambridgesoft.com/) was used for verification of IUPAC names. 
micelles is also possible for many other small molecules acting as chemical chaperones, which can impair the formation of amyloid aggregates. Furthermore, the interaction between negatively charged $C R$ molecules and $A ß$ peptides is suggested to become possible by folding a $ß$-hairpin structure stabilized by electrostatic interactions in the monomeric $A ß$ peptide. This allows binding of sulfated dyes like CR between K16 and K28 of Aß peptide [86].

$\mathrm{Wu}$ et al. [85] identified with molecular dynamics studies seven potential binding sites of $C R$ at the $B$ sheet structures of amyloid fibers. Early dyes used in histology have been reported to bind simultaneously to $A ß$ and to tau protein in $\mathrm{AD}$. This is not of relevance in non-AD tauopathies like Pick disease, progressive supranuclear palsy (PSP) or corticobasal degeneration (CBD).

Meanwhile, there is postulated deposits of tau proteins correlate better with cognitive alterations in $\mathrm{AD}$ than $\mathrm{A} B$ [82].

Reinke \& Gestwicki [87] discussed a similar binding mode also for curcumin [Figure 1, (2)] and chrysamine G. Differences in the efficiency of diverse ligands in binding to various stages of the cascade from monomeric soluble peptides to insoluble aggregates have been suggested for all the time of investigations in this field [88]. A fluor-labelled derivative of curcumin [F4curcumin; Figure 1, (3)] was investigated in rodent models [89]. A low efficiency in transfer through the blood brain barrier (BBB) and the presence of two labelled metabolites have been reported as limitations of the use of this compound for in vivo imaging.

Ligands suitable for in vivo visualization of amyloid have been reviewed, recently, by Oukoloff et al. [18]. Many of these have been discovered as medicinal chaperones, which can potentially decrease or remove Aß-deposits or delay formation of Aß-oligomers or fibrils [18] [69] [90].

Suitable agents for in vivo imaging should be highly selective compounds interacting directly with protein aggregates or their pre-stages. Many of the compounds described previously show appropriate affinities to senile plaques [18] [69]. Additionally, the tissue content of protein deposits in late stage of the disease is relatively high [91]. However, Harrison et al. [90] claimed, similarly to Hostetler (for ligands of neuropeptide receptors) [92] [93] and Lipinski et al. [94] (for classical G-protein coupled receptors), properties for amyloid ligands with following thresholds: $\mathrm{K}_{\mathrm{d}}<20 \mathrm{nM}, \log \mathrm{P}<3$ or better $<2.5$ and lack of P-gP susceptibility.

Among compounds directly interacting with amyloid fibrils, $\left[{ }^{18} \mathrm{~F}\right]$ FDDNP [Figure 1, (4)] has been employed as the first structure in clinical trials with AD patients [95]-[100]. The intention was to identify pathological deposition of amyloid already during the pre-clinical stage as well as neuritic and diffuse amyloid. FDDNP has been reported to be weakly associated with neurofibrillar tangles in $\mathrm{AD}$, with $\mathrm{A} ß$ and tau [76] [101].

The amyloid ligand employed most frequently in PET studies is the thioflavin Pittsburgh compound B [PIB; Figure 1, (5)] [98] [102] [103]. The efficiency of $\left[{ }^{3} \mathrm{H}\right] \mathrm{PIB}$ binding and of in vivo $\mu$ PET $\left[{ }^{11} \mathrm{C}\right] \mathrm{PIB}\left(\left[{ }^{11} \mathrm{C}\right] 6-\mathrm{OH}-\mathrm{BTA}-1\right)$ experiments revealed marked variations, with one PIB molecule bound per 1000 amyloid 
molecules in double transgenic (tg)PS1/APP mouse models vs 500 binding sites per 1000 molecules in human cortical tissue [88]. $B_{\max }$ values for human brain homogenates are described with 1407 pmoles/g wet weight and high affinity $K_{d}$ of $2.5 \mathrm{nM}$ [102] [103]. However, PIB [Figure 1, (5)] bound in the different types of $\mathrm{AD}$ to regions affected by the disease but also in such which are unaffected [75]. On the other hand, PIB as well as the related compound BF227 [Figure 2, (14)] [104] have been described to bind tightly to senile plaques but not to tau in non-Alzheimer tauopathies [101].

PIB became the origin of a series of benzothiazole compounds as candidates for chemical/medicinal chaperones or diagnostic PET probes e.g. $\left.{ }^{18} \mathrm{~F}\right] \mathrm{PIB}\{[$ Figure 1 , (6) $]$ = flutemetamol/GE-067;(GE-Healthcare) $\}$ [97] as well as FeO-BTA-compounds [Figure 1, 8, 9] [98] and AZD 2184 [Figure 1, (7)] [91]. Already early<smiles>CNc1ccc(-c2cc3cc(O)ccc3o2)c(F)n1</smiles>

13<smiles>[18F]CCOc1ccc2nc(/C=C/c3cnc(N4CCCCC4)s3)oc2c1</smiles><smiles>CN(C)c1ncc(/C=C/c2nc3ccc(OC(CO)C[18F])cc3o2)s1</smiles><smiles>CN(C)c1ncc(/C=C/c2nc3ccc(OCC[18F])cc3o2)s1</smiles>

14<smiles>OCC(C[18F])Oc1ccc2nc(/C=C/c3cnc(N4CCOCC4)s3)oc2c1</smiles><smiles>CNc1ccc(-c2cn3c(n2)sc2cc(OCC[18F])ccc23)cc1</smiles><smiles>Cn1ccc2cc(-c3nc4ccc([NH3+])nc4o3)cnc21</smiles>

19<smiles>CNc1ccc(-c2cc3cc(OCCOCCOCC[18F])ccc3o2)cc1</smiles><smiles>CNc1ccc(-c2cc3cc(OCCOCCOCC[18F])ccc3o2)cn1</smiles>

Figure 2. Aß ligands: 13 2-(2-(fluoro- $\left.{ }^{18} \mathrm{~F}\right)-6$-(methylamino)pyridin-3-yl)benzofuran-5-ol; 14 (E)-5-(2-(6-(2-(fluoro- $\left.{ }^{18} \mathrm{~F}\right)$ ethoxy)benzo[d] oxazol-2-yl)vinyl)-N-methyl-N-(methyl $\left.-{ }^{11} \mathrm{C}\right)$ thiazol-2-amine; 15 (E)-6-(2-(fluoro- $\left.{ }^{18} \mathrm{~F}\right)$ ethoxy)-2-(2-(2-morpholinothiazol-5-yl)vinyl) benzo[d]oxazole; 16 (E)-3-(fluoro- $\left.{ }^{18} \mathrm{~F}\right)-2-((2-(2-(2-$ morpholino-thiazol-5-yl)vinyl)benzo [d]oxazol-6-yl)oxy)propan-1-ol; 17 (E)-2-((2-(2-(2-(dimethylamino) thiazol-5-yl) vinyl) benzo[d] oxazol-6-yl)oxy)-3-(fluoro- ${ }^{18} \mathrm{~F}$ )propan-1-ol; 18 4-(7-(2-fluoro- ${ }^{18} \mathrm{~F}$-ethoxy)benzo[d] imidazo-[2,1-b]thiazol-2-yl)-N-methylaniline; 19 5-fluoro- ${ }^{18} \mathrm{~F}-2$-(1-methyl-1H-pyrrolo [2,3-b] pyridin-5-yl)oxazolo[5,4-b] pyridine; 20 4-(5-(2-(2-(2-fluoro- ${ }^{18}$ F)ethoxy)ethoxy)benzofuran-2-yl)-N-methylaniline; 21 5-(5-(2-(2-(2-fluoro- $\left.{ }^{18} \mathrm{~F}\right)$ ethoxy)ethoxy)benzo-furan-2yl)-N-methyl-pyridin-2-amine. 
comparison of the drug uptake (SUV, standard uptake values) in grey matter and in white matter of the brain; and on SUV data in general, rose questions on the diagnostic value of the respective PET scans [105]. For $\left[{ }^{11} \mathrm{C}\right]$ PIB was observed the non-specific retention of the tracer was higher in controls than in $\mathrm{AD}$ patients [115].

For $\left[{ }^{18} \mathrm{~F}\right]$ flutemetamol $\left(\left[{ }^{18} \mathrm{~F}\right] \mathrm{PIB}\right)$ [Figure 1, (6)], variable uptake with SUVRs between 2.0 and 3.5 had been described in white matter. SUVRs between 1 and 3.0 were reported for cortex and striatum. A $100 \%$ sensitivity and specificity described Wong et al. [106] in a report on application of flutemetamol [Figure 1, (6)] in patients with normal-pressure hydrocephalus which can cause dementia. The authors compared bioptic material obtained in vivo, PET measurements and immune-histochemical identification of fibrillary amyloid (antibody 4 G8) with a composite SUVR including frontal cortex, anterior cingulate and posterior cingulate gyrus, precuneus, lateral temporal and parietal cortex. However, even for $\left[{ }^{11} \mathrm{C}\right] \mathrm{PIB}$ has been suggested that different conformations of Aß deposits can render reduction or also absence of tracer binding [105].

Neumaier et al. investigated [98] fluorethoxy benzothiazole derivatives proposed originally by Berndt et al. [107] and Zheng et al. [108] [109] with optimized $\log \mathrm{P}$ values. While two of the three fluorine-labelled derivatives showed $\log \mathrm{P}_{\text {oct }}$ values close to PIB and FDDP at 2.1 and 2.4, only one structure, 6-FeOtBTA-1 [Figure 1, (9)], showed with a $\mathrm{K}_{\mathrm{i}}$ of $7.2 \mathrm{nM}$ also an affinity suitable for in vivo imaging. $K_{\mathrm{i}}$ was determined with $\mathrm{A} ß(1-40)$ peptide monomers aggregated in PBS and using BTA-1 for displacement of the test compounds. Tracer accumulation was investigated in wild type of severe combined immunodeficiency (SCID) mice [107].

The Astra Zeneca benzothiazole compound AZD 2184 [Figure 1, (7)] shows a slightly better $\log$ P than PIB [90] and, correspondingly, lower labelling of white matter; but $\left[{ }^{11} \mathrm{C}\right] \mathrm{AZD} 2184$ achieves highest cerebral accumulation within $30 \mathrm{~min}$ in $\mathrm{AD}$ patients and standard uptake values between 1.19 and 2.57 [110].

Another approach was the advancement of the stilbene derivative SB-13 [Figure 1, (10)] [111] to the styrylpyridine $\left[{ }^{18} \mathrm{~F}\right.$ ]florbetapir [Figure 1, (11); Eli lilly] [112] and the stilbene derivative $\left[{ }^{18} \mathrm{~F}\right]$ florbetaben [Figure 1, (12); BAY 94-9172].

Although florbetapir [Figure 1, (11)] has been approved 2012 by the Food and Drug Administration (FDA) [113] there are also fundamental pharmacokinetic points of questioning summarized 2013 by Kepe et al. [105]. These include e.g. the very fast metabolization of florbetapir observed in mice [105] as well as for instance the role of tau protein in AD [114].

On the other hand, Reiman et al. [115] and Fleisher et al. [116] published at the same time a cross sectional study with florbetapir. Patients in the age between 20 and 56 years carrying PSN1 (presenilin) E280 mutations were subjected to florbetapir PET and compared with non-carriers. Amyloid Aß deposits could be detected in individuals with the mutation 21 years before the predicted age of the onset of dementia [116].

Because all benzothiazole derivatives showed a large fraction bound to white 
matter, Jureus et al. [117] proposed in 2010 the benzofuran derivative AZD 4694 [Figure 2, (13)] developed in cooperation with Astra Zeneca [117]. The authors submitted the new substance to comparative in vitro tests, to in vivo and to clinical tests including binding assays in different mixtures of $A ß(1-40)$ fibrils and $A ß(1-42)$ fibrils, autoradiographic analyses, in vivo testing in transgenic mice , in rats and in $\mathrm{AD}$ patients.

Ni et al. [91] described the distribution of low and high affinity binding sites in 23 patients with $A D$. The probes for in vitro imaging included [ ${ }^{3} \mathrm{H}$ ] PIB for autoradiographic comparison (GE healthcare), AV-45 (the commercially available florbetapir), AV-1 (M. Newington (GE healthcare).

The measurement shows in AD patients accumulation of Aß between 1000 and $2000 \mathrm{fmol} / \mathrm{mg}$ wet weight in the frontal cortex as well as between 100 and 900 $\mathrm{fmol} / \mathrm{mg}$ in the hippocampus [91]. However, also differences in the distribution of $\mathrm{A} ß$ ligands depend on the time of onset of $\mathrm{AD}$. Late-onset $\mathrm{AD}$ afflicts predominantly medial temporal lobe; early-onset $\mathrm{AD}$ typically results in accumulation of AV1451, for instance, in occipital, parietal and frontal regions [75] due to enhanced neurofibrillary tangles, probably. Moreover, carriers of the APOE $\varepsilon 4$ allele show medial, lateral and parietal binding of AV1451. High specificity of florbetaben has been demonstrated by Fodero-Tavoletti et al. [57] by comparison with immunostaining of amyloid, tau-protein and $\alpha$-synuclein in postmortem sections of an $\mathrm{AD}$ patient [57]. Furthermore, appropriate pharmacokinetic properties with an uptake of $6 \%$ of the injected dose in the human brain have been observed and recommend the substance for clinical application [118] [119].

More recently, benzoxazole imaging probes have been proposed by Furumoto et al. (Tohoku University) [120]. The first of these compounds, $\left[{ }^{11} \mathrm{C}\right] \mathrm{BF} 227$ [Figure 2, (14)], was described as a ligand with high sensitivity in patients with mild cognitive impairment (MCI) but with moderate specificity (71.4\%). The compound was suggested as suitable to differentiate in MCI between converters and non-converters to $\mathrm{AD}[120] .\left[{ }^{18} \mathrm{~F}\right] \mathrm{BF} 227$ and further benzoxazole derivatives (THK 525 [Figure 2, (15)], THK 702 [Figure 2, (16)], [ ${ }^{18} \mathrm{~F}$ ] FACT [Figure 2, (17)], THK 727) were analyzed and, subsequently, a 2-ethenyl-benzoxazole was chosen for biological and potential clinical applications. In vitro binding assays revealed in Aß fibrils for $\left[{ }^{18} \mathrm{~F}\right.$ ] FACT [Figure 2, (17)] $\mathrm{K}_{\mathrm{d}}$ values of $9.4 \mathrm{nM}$ and $263 \mathrm{nM}$. Also these series of potential ligands showed initially a fast increase in brain uptake followed by a rapid clearance and by a decrease of the retention of the tracers in grey matter below that of the white matter. In comparison to retention in blood, the tracers [120] showed only small differences.

SUVR for complete AD was 2.4 in lateral temporal cortex and 2.14 in posterior cingulate.

A competitor to florbetaben with improved pharmacokinetics was provided 2013 by Yousefi et al. [121] with the benzoimidazothiazol FIBT [Figure 2 (18)]. The authors tested the substance in tg mice in comparison to PIB and florbetaben. Whereas $\mathrm{K}_{\mathrm{d}}$ and lipophilicity were reported to resemble that of florbetaben, the compound showed lower retention in white matter and promising distribution in brain tissue of a tgAPP/PSN1 mouse model [121]. 
The authors described an improved ratio of specific to non-specific binding during the time course of $\left[{ }^{18} \mathrm{~F}\right]$ FIBT accumulation in comparison to florbetaben [121], however, in pre-clinical experiments in tg animals.

Series of aryl oxazoles were synthesized by Harrison et al. [90] (Merck). The compound chosen among these for further investigation was MK 3328 [Figure 2, (19)] [90] [92]. This compound and the benzoxazole substances $\left[{ }^{18} \mathrm{~F}\right] \mathrm{FACT}$ as well as $\left[{ }^{18} \mathrm{~F}\right] \mathrm{FIBT}[120]$ fulfill the requirements set by Harrison et al. as threshold for affinities, $\log \mathrm{P}$ and P-gp susceptibility.

Furthermore, Ono et al. [122] presented with $\left[{ }^{18} \mathrm{~F}\right]$ FPBYBF -2 [Figure 2, (21)] a benzofuran compound with fluoro-polyethylene glycol side chain and a monomethylamino group as PET ligand with appropriate pharmacodynamic and pharmacokinetic properties $\left(\mathrm{K}_{\mathrm{i}} 3.84 \mathrm{nM}\right.$ and $\left.\log \mathrm{P} 2.41\right)$.

\subsection{Tau Protein}

\subsubsection{Isoforms of Tau Protein, Functional Properties and Tauopathies}

Tau protein has been extensively investigated by the first time in the 70ties of the last century (for review see [56]) and was isolated from porcine brain in 1975 [123]. It was regarded originally rather as a protein co-expressed with amyloid than as a predominant inductor of structural protein disturbance or cellular destruction. Meanwhile, 80 diseases causing missense intrinsic silent mutations of the gene coding for tau proteins have been described [56] [124]. Six tau isoforms are known. Tau protein is the largest among the peptides regarded as hallmark of dementia, and fibrillary deposits of its hyperphosphorylated version are targets of clinical PET with rising importance for differential diagnostics in dementia. In the brain, only small tau proteins are relevant (ca 410 a.a.r.) whereas big tau protein was observed in peripheral organs (695 a.a.r.) [10]. At least, tau protein is coded by one gene: MAPT (microtubule associated protein tau) on chromosome 17q21 [review 124]. Tau protein belongs functionally into the group of microtubule associated proteins (MAPS). The phosphorylated protein binds to the microtubules supporting its assembly. However, if hyperphosphorylated it can acquire the propensity to interact with a multitude of different proteins [10] [11] [70]. Hyperphosphorylated tau protein is the main compound of neurofibrillary tangles [124] and of insoluble Aß aggregates. Close to 40 abnormally hyperphosphorylated sites have been identified in tau proteins of $\mathrm{AD}$ patients.

Tauopathies include some variants of frontotemporal lobe dementia (FTLD), which have been reported to account for $10 \%$ to $20 \%$ of all cases of dementia [17] [70] [114]. Moreover, tau protein is associated with Down's syndrome, Guam Parkinsonism dementia complex, frontotemporal dementia with PD linked to chromosome 17 and PSP [70].

Depending on the presence of three or four tandem repeats in the microtubule binding domain of tau proteins, different phenotypes of tau protein malfunction can occur [114].

\subsubsection{Tau Protein Ligands for PET Imaging of the Brain}

Several clinical trials with ligands of tau protein have been reported during the 
last two decades [125] [126] [127]. Recent reviews on tau protein ligands suitable for cerebral PET imaging focus on three lead structures: quinoline derivatives, benzimidazole derivatives and benzoindole pyridine derivatives [70]. Most sensitive compounds have been found in the group of quinoline derivatives with THK 5105 [Figure 3, (22)], THK 523 [Figure 3, (23)], THK 5117 [Figure 3,<smiles>CN(C)c1ccc(-c2ccc3cc(OCC(F)(F)F)ccc3n2)cc1</smiles><smiles>Nc1ccc(-c2ccc3cc(OCC[In])ccc3n2)cc1</smiles>
23<smiles>CNc1ccc(-c2ccc3cc(OCC(O)[In+])ccc3n2)cc1</smiles><smiles>Fc1ccc(-c2ccc3c(c2)[nH]c2ccncc23)cn1</smiles><smiles>[18F]CCC1CCN(c2ccn3c(c2)nc2nc4ccccc4nc23)CC1</smiles>

26<smiles>CC(C)(C)Nc1ccc(C=CC=Cc2nc3ccc(O)cc3s2)cn1</smiles><smiles>Fc1ccc2cnc(-n3ccc4ccncc43)cc2c1</smiles><smiles>Nc1ccc2cc(-n3ccc4ccncc43)ncc2c1</smiles>

29<smiles>COc1ccc2cc(-n3ccc4ccncc43)ncc2c1</smiles><smiles>FCNc1ccc2cnc(-n3ccc4ccncc43)cc2c1</smiles>

30<smiles>Nc1c(-c2ccc(F)c([18F])c2)ncc2ccncc12</smiles>

31

Figure 3. Tau protein ligands: 22 2-((2-(4-(dimethylamino)phenyl)quinolin-6-yl) oxy)-1-fluo- ${ }^{18} \mathrm{~F}$-roethan-1-ol; 23 4-(6-(2-fluoro- ${ }^{18} \mathrm{~F}$-ethoxy) quinoline-2-yl)aniline; 24 1-fluoro- ${ }^{18} \mathrm{~F}-2-((2-(4-($ methylamino $)$ phenyl)quinoline-6-yl)oxy)ethan-1-ol; $25 \quad 7$-(6-fluoropyridin-3-yl)-5H-pyrido [4,3-b]indole; 26 2-(4-(2-fluoro- ${ }^{18} \mathrm{~F}$-ethyl)piperi-din-1-yl) benzo[4,5] imidazo [1,2-a] pyrimidine; $272-\left((1 \mathrm{E}, 3 \mathrm{E})-4-\left(6-\left({ }^{11} \mathrm{C}-\right.\right.\right.$ methylamino $)$ pyridin3-yl)buta-1,3-dien-1-yl)benzo[d] thiazol-6-ol; 28 6-fluoro- ${ }^{18} \mathrm{~F}-3-(1 \mathrm{H}-$ pyrrolo[2,3-c]pyridin-1-yl)isoquinoline; 293 -(1H-pyrrolo[2,3-c]pyridin-1-yl)isoquinoline-7-amine; 307 methoxy-3-(1H-pyrrolo[2,3-c]pyridin-1-yl)isoquinoline; $31 \mathrm{~N}$-(fluoro- ${ }^{18} \mathrm{~F}-$ methyl)3 - $\left(1 \mathrm{H}\right.$-pyrrolo [2,3-c]pyridin-1-yl)isoquinoline-6-amine; 32 6-fluoro- ${ }^{18} \mathrm{~F}-3-(1 \mathrm{H}$-pyrrolo[2,3-c]pyridin-1-yl)isoquinoline-5-amine. 
(24)] and $K_{\mathrm{d}}$ values of 1-5 nM, $1.67 \mathrm{nM}$ and 5-11 $\mathrm{nM}$ as well as $\log \mathrm{P}$ values between 2 and 3. Recently, further improvement in pharmacokinetics was obtained with the pyridine quinoline THK-5351 [128] with a $\log \mathrm{P}$ of 1.49 and a $\mathrm{K}_{\mathrm{d}}$ of 2.9 nM. The pyridine-pyridoindole derivative T807 [Figure 3, (25)] (AV-1451) showed a $\mathrm{K}_{\mathrm{d}}$ of $14.6 \mathrm{nM}$ and a $\log \mathrm{P}_{\text {calc }}$ of 3.4 as well as a measured value of 1.67 [75]. Duykaerts demonstrated [129] the compound THK 523 [Figure 3, (23)] bound in a mouse model of $A D$ to $A ß$, but not to NFT (neurofibrillary tangles). However, Aß as well as NFT were labelled in human brain sections. Pyridoindolpyridine quinoline derivatives and benzoimidazoindole derivatives showed best feasibility as PET tau protein markers [75] [82] [130].

The first PET tracer with appropriate selectivity for NFT was T807 [130]. Meanwhile, T807 [Figure 3, (25)] (AV-1451) is the most widely investigated NFT tracer [131]. Recently, Brier et al. [82] compared this PET tracer with florbetapir [Figure 1, (11)] as Aß label in a clinical study including participants with presence or absence of cognitive impairment. Participants with normal cognitive performance showed low tracer accumulation in the brain, but not in basal ganglia, whereas cognitive impairment was associated with increased accumulation in temporal lobes as well as in the other parts of cerebral cortex [82]. In general, the topographies of tau protein and $A ß$ were confirmed to be distinct. However, a good correlation was reported if the regions with most intensive accumulation of the tracers were in the focus. These were for tau protein: medial temporal lobe, parietal cortex and precuneus.

The pyridoindole derivative T808 showed a good correlation between PET measurements and postmortem pathological analysis in a person, which died five month after PET scanning of paired helical filament tau (PHF) [70] [132] [133].

$\left[{ }^{18} \mathrm{~F}\right]$ THK 5105 has been tested by Okamura et al. in comparison to $\left[{ }^{11} \mathrm{C}\right] \mathrm{PIB}$ in a clinical study with participants between 63 and 82 years of age [134]. In inferior temporal cortex, two hours p.i., a SUVR (standard uptake value ratio) of 1.4 reflected an enhancement in retention of the tracer in patients with $\mathrm{AD}$ compared to healthy subjects [134]. The butadienylbenzothiazol PBB3 [Figure 3, (27)] proposed by Maruyuma et al. [101] showed in a clinical study a fast wash-out and lower brain uptake than T807, but a 40 - 50 times higher binding at NFT than at senile plaques as well as low white-matter binding [17] [101].

A promising series of pyrrolopyridine isoquinolines [Figure 3, (28-32)] has been presented by Walji et al. [135], for which initial clinical trials are completed. The binding analysis of tau protein and Aß shows best selectivity for tau protein compared to amyloid. A first isoquinoline compound among these structures investigated already with PET in monkey is MK-6240 [Figure 3, (32); Merck Sharp \& Dohme]. A $\mathrm{K}_{\mathrm{i}}$ of $0.36 \mathrm{nM}$ was observed for MK-6240 in NFT rich brain homogenates using the selective, high affinity ligand $\left[{ }^{3} \mathrm{H}\right]$ NFT-355 in the displacement study. Log D was $3.32(\log$ P 2.06) and P-gp (Permeability-glycoprotein) susceptibility ratio 1.3 showing the compound is not a substrate of Pgp [130] [135].

MK-6240 was, like other compounds of the isoquinoline series, deduced from 
a pyrrolopyridine-methylpyridine as minimal pharmacophore [128]. Some of these structures show improved affinities at NFT and a $B_{\max }$ in the range between 80 and $145 \mathrm{nM}$ in NFT rich AD human membrane homogenate. However, MK-6240 achieved the highest binding potential as well as the highest score in a CNS specific multiparametric optimization tool developed by Pfizer [136] [137] and employed by the authors for the selection of the optimal lead structures. The PET studies in monkey showed very convincing autoradiographic results, especially for the comparative binding assays of tissue with normal phosphorylated tau and hyperphosphorylated tau protein [135].

The first PET images in monkey showed, however, again absence of differences between retention in white and in grey matter of the brain [135].

\section{3. $\alpha$-Synuclein}

\subsubsection{Properties, Distribution and Synucleopathies}

The 140 a.a.r. protein $\alpha$-synuclein is encoded by the genes SNCA and PARK1 on the chromosome 4q21 [138]. $\alpha$-Synuclein is a presynaptic protein, unfolded in native state and soluble [20]. In solution, the protein adopts a coil conformation. Similar to the other proteins established as hallmarks of the diverse entities of dementia also $\alpha$-synuclein occurs in the brain in various constitutions. In Parkinson disease $(\mathrm{PD})$ there is a propensity to assemble to protein aggregates. Moreover, in the different kinds of synucleopathies; it can be found in different cells and in different subcellular compartments [20] [58] [139] [140]. Lewy bodies are hallmarks of PD within neurons, whereas the protein aggregates in patients suffering from multiple system atrophy (MSA) are observed also in oligodendrocytes [141] [142]. $\alpha$-Synuclein is frequently co-localized with Aß, tau protein but also with synphilin 1 (synuclein $\alpha$-interacting protein) and parkin (part of the E3 ubiquitin ligase complex) [140].

The soluble $\alpha$-synuclein can assemble to fibrils and finally to amyloid-like aggregates as compounds of Lewy bodies. These are the pathological hallmarks of different forms of PD-related dementia [8]-PD with dementia and, if dementia follows within one year after motoric symptoms have started, dementia with Lewy bodies (DLB) [8] [141]. Spreading of $\alpha$-synuclein in the brain is suggested to follow during prodromal stages and progression of the diseases in general the Braak stages similarly to AD [38] [39] [141]. The clinical stages are classified according to Hoehn and Yahr [142] and show already motoric deficits of the diseased individuals, but also more general symptoms like gastrointestinal dysfunction, or hyposmia. The initial lesion in PD has been identified in dopaminergic neurons of the A9 region of substantia nigra, pars compacta [143].

Desires for labelled ligands of $\alpha$-synuclein have been revealed with increasing frequency during the last years [144] with the aim of better discrimination of PD and similar diseases like PSP, CBD or MSA [20] [144].

\subsubsection{Small Molecule Ligands of $\alpha$-Synuclein}

A first radiolabeled $\alpha$-synuclein ligand has been described by Bagchi et al. [20]. The phenothiazine SIL 23 [Figure 4, (33)] was primarily tested for competition 
<smiles>CC=CCOc1ccc2c(c1)Sc1cc([N+](=O)[O-])ccc1N2</smiles>

33<smiles>O=[N+]([O-])c1ccc2c(c1)Sc1cc(OC/C=C/Br)ccc1N2</smiles><smiles>O=[N+]([O-])c1ccc2c(c1)Sc1cc(OCC[18F])ccc1N2</smiles><smiles>O=[N+]([O-])c1ccc2c(c1)Sc1cc(OCC(O)[18F])c(O)cc1N2</smiles>

35

36<smiles>O=[N+]([O-])c1ccc2c(c1)Sc1ccccc1N2</smiles><smiles>O=[N+]([O-])c1ccc2c(c1)Sc1cc(Br)ccc1N2</smiles>

37<smiles>Brc1cccc(-c2cc(-c3ccc4c(c3)OCO4)n[nH]2)c1</smiles>

Figure 4. $\boldsymbol{a}$ synuclein ligands: 33 (E)-3-((3-iodo- ${ }^{124} \mathrm{I}$-allyl)oxy)-7-nitro-10H-phenothiazine; 34 (E)-3-((3-bromo- ${ }^{76} \mathrm{Br}$-allyl)oxy)-7-nitro-10H-phenothiazine; 35 3-(2-fluoro- ${ }^{18} \mathrm{~F}$ ethoxy)-7-nitro-10H-phenothiazine; 36 3-(2-fluoro- ${ }^{18} \mathrm{~F}$-2-hydroxyethoxy)-7-nitro- $10 \mathrm{H}$ phenothiazin-2-ol; 37 3-nitro-10H-pheno-thiazine; 38 3-bromo- ${ }^{76} \mathrm{Br}-7$-nitro- $10 \mathrm{H}$-phenothiazinet; 39 3-(benzo[d] [1,3]dioxol-5-yl)-5-(3-bromo- ${ }^{76} \mathrm{Br}$-phenyl)-1H-pyrazole.

with thioflavine $T$ in synthetic synuclein fibrils where a $K_{i}$ of $60 \mathrm{nM}$ was observed and a $K_{d}$ of $148 \mathrm{nM}$. A Scatchard plot showed a one-site binding mode of the tracer [20]. Comparison of synthetic $A ß$ (1-42) fibrils and recombinant tau fibrils resulted in a $K_{d}$ of $635 \mathrm{nM}$ with a $B_{\max }$ with $23.7 \mathrm{pmol} / \mathrm{nmol}$ at $A ß$ and for tau fibrils in a $K_{d}$ of $230 \mathrm{nM}$ with a $B_{\max }$ of $4.57 \mathrm{pmol} / \mathrm{nmol}$. SIL 23 has been introduced as a SPECT (single-photon emission computed tomography) tracer and is shown in Figure 4 labelled with the non-pure PET isotope iodine-124. Structural modification of the phenothiazine compound led to the fluorine associated derivative SIL 26 [Figure 4, (35)] with slightly higher affinity to $\alpha$-synuclein fibrils and moderate selectivity between synuclein, tau (7 fold lower) and Aß 1-42 (6 fold lower affinity).

Binding at synuclein has been reported also for PIB and BF 227 as PET tracers [140]. SIL 22, SIL 28 and SIL 3B [Figure 4; $(34,37,38)$ ] are further structures beyond the scope of phenothiazine derivatives revealed by Bagchi's and Prusiner's group [20] [145]. A hydroxyl-substituted version of SIL 26 [Figure 4, (36)] 
shows with 2.61 an appropriate $\log \mathrm{P}$ in contrast to the other compounds mentioned above. However, the pharmacodynamics properties of this compound have to be elucidated.

Some compounds developed originally as chemical chaperones or label of prions (see also chapter 2.4.) [146] could suppress additionally, the formation of aggregates of $\alpha$-synuclein in cellular models (reduction of pore formation in membrane and trend to smaller oligomers and monomers) and in different in vivo models (sub-acute MPTP mouse model, long-term transgenic mouse based on expression of human A30P $\alpha$-synuclein). An example is the dioxol bromophenyl compound anle 138b [Figure 4, (39)] [147]. The apparent $\mathrm{EC}_{50}$ for the inhibition of aggregate formation was $2.8 \mu \mathrm{M}$ [147]. The reduction in $\alpha$-synuclein was restricted to oligomer formation, while the total level of synuclein remains unchanged. However, behavioral tests demonstrated also a reduction of fluctuations in motoric function to control levels. Additionally, the disease-free interval in these animals was enhanced by 10 weeks [147].

\subsection{Prions}

\subsubsection{Constitutive and Infectious Isoforms of Prion Protein}

Prions in the context of transmissible infections are known in humans (as Creutzfeld-Jacobs-disease; Gerstmann-Sträussler disease [148], kuru or fatal familial insomnia), in cattle (as bovine spongiform encephalopathy) [148], in cervids (as chronic wasting disease), in sheep (as scrapie) [149]. $\operatorname{PrP}^{\mathrm{C}}$ and $\operatorname{PrP}^{\mathrm{sc}}$ have been characterized by different extent. Common models have been established in mice, hamsters; or diverse cellular models e.g. yeast.

$\mathrm{PrP}^{c}$ is located in the plasma membrane. It has been crystallized and described by NMR (nuclear magnetic resonance). It is the intracellular partner of the infectious $\operatorname{PrP}^{s c}$ which can use the $\operatorname{PrP}^{c}$ protein as substrate and template for the propagation of its own replication [12] [149] [150].

The structure of $\operatorname{PrP}^{\mathrm{sc}}$ is less well known than that of $\operatorname{PrP}^{\mathrm{c}}$. One model of fibril formation by $\operatorname{PrP}^{\mathrm{sc}}$ used successfully in solid state NMR is the filamentous fungus Podospora anseri [149]. Several strains of the infectious protein have been identified. Common features of the prion diseases are neuronal loss, vacuolization and accumulation of amyloid in the CNS what result in humans in clinical symptoms like ataxia, dementia and further neurological abnormalities. The extent, velocity and, probably, also the motoric cerebral region predominantly affected depends from the strain of $\operatorname{PrP}^{\text {sc }}$ inoculated [35] [149].

$\operatorname{PrP}^{c}$ is a 254 a.a.r. peptide [12] which has an anchor region of 22 a.a.r. at the $\mathrm{C}$ terminus and a secretory signal peptide at the $\mathrm{N}$-terminus. The residues $23-124$ for a sequence of octapeptide-repeats framed by two positively charged clusters of 5 a.a.r. and 23 a.a.r $(111-134)$ connect this proximal stretched region with the globular $\mathrm{COOH}$ region. $45 \%$ of $\mathrm{PrP}^{\mathrm{c}}$ are helical and only two short sequences of $\operatorname{PrP}^{c}$ are $ß$ sheets. PrPsc shows only $30 \%$ helical domains and $45 \% ß$ sheets [12].

A role of $\mathrm{PrP}^{c}$ in the protection of the tissue by binding of toxic concentrations of $\mathrm{Cu}^{2+}, \mathrm{Zn}^{2+}$ or $\mathrm{Mn}^{2+}$ is regarded, currently, as a physiological function of the membrane protein. Observations on an increase of $\operatorname{PrP}^{c}$ in further neurode- 
generative diseases like Parkinson and Alzheimer's Disease and an increase in stress susceptibility in $\mathrm{PrP}^{\mathrm{c}}$-/- mice support the presumption of neuroprotective actions by $\operatorname{Pr}^{c}$ [149] [150]. However, there is a multitude of experimental observations, which suggest further physiological functions of the constitutive prion protein e.g. in neuritogenesis, maintenance of membrane homogeneity or activation of T-lymphocytes [150].

The diseases initiated by $\mathrm{PrP}^{\mathrm{sc}}$ formation are regarded as gain-of toxic function diseases.

$\operatorname{PrP}^{c}$ is soluble in mild detergent and can be digested by proteinase $\mathrm{K}$, whereas $\mathrm{PrP}^{\mathrm{sc}}$ forms insoluble aggregates and contains a $\mathrm{C}$-terminal part insensitive to proteinase [150].

The report by Mallucci et al. 2003 [34] [35] demonstrating the prevention of pathological prion species $\mathrm{PrP}^{\mathrm{sc}}$ in mice depleted of $\mathrm{PrP}^{\mathrm{c}}$ was a milestone in the research for antiprion compounds and also for drugs decreasing amyloid aggregates.

\subsubsection{Ligands of $\mathrm{PrP}^{\mathrm{c}}$ and $\mathrm{PrPsc}$}

Ghaemmaghami et al. [21] identified four groups of small-molecule scaffolds as potential sources of prion ligands with therapeutic or diagnostic impact. These were 2-aminothiazoles, quinazolines, hydroxyquinolines and bezoxazoles [21]. Ghaemmaghami et al. preferred as the main field of efforts the 2-aminothiazole and provided a series of compounds [Figure 5, (40 - 49)] four years later [149]. Among the 2-aminothiazoles were identified some structures with moderate affinities in lower $\mathrm{nM}$ range, most of them, however, with inappropriate $\log \mathrm{P}$ values. Compound 26 [Figure 6, (52)], a morpholino-2-aminothiazole in Ghaemmaghami's report achieves with 2.34 also a $\log \mathrm{P}$, which promised an acceptable distribution between grey and white matter and an appropriate kinetics via the bbb.

Many of the early small molecular chaperones, which inhibit propagation of prion formation in experimental systems [151], show cross affinities among the different amyloids containing Aß, $\alpha$-synuclein, tau protein or prions [152] [153]. Also in recent works this remains a problem in the search for specific in vivo imaging agents, even if the therapeutic impact can be promising. For instance, Wagner et al. [147] favored in a series of 3,5-diphenyl pyrazole derivatives the dioxol bromophenyl compound anle138b [Figure 4, (39)], highly efficient in inhibition of several prion strains, in ScN2a and SMB (scrapie mouse brain cells infected with the Rocky Mountain Laboratory (RML) scrapie strain, in diverse in vitro and in vivo models of prion conversion and expression of prion disease in mice. The drug bound not to the monomers of $\operatorname{PrP}^{\text {sc }}$ but modified assembly of oligomers. A marked reduction in $\mathrm{PrP}^{\mathrm{sc}}$ formation could be observed also in vivo if the treatment started 80 days after inoculation of $\operatorname{PrP}^{\mathrm{sc}}$ and continued until day 120 p.i.

The intention to develop small-molecule prion ligands starting from scaffolds, which are known to cross the bbb [154], drew the attention to psychoactive drugs and, finally, to tricyclics of acridine and phenothiazine type [155]. BiCap- 
<smiles>N=Cc1ccncc1</smiles><smiles>Cc1ccnc(Nc2nc(-c3ccc(-c4ccccn4)s3)cs2)c1</smiles>

42<smiles>c1ccc2cc(Nc3nc(-c4ccncc4)cs3)ncc2c1</smiles>

44<smiles>COc1ccc(-c2csc(Nc3cncc4ccccc34)n2)cc1OC</smiles><smiles>Cc1cccc(Nc2nc(-c3ccc(-c4ccccc4)cc3)cs2)n1</smiles><smiles>O=C(CN1CCCC1)Nc1ccc(Cc2ccc(NC(=O)CN3CCCC3)cc2)cc1</smiles>

41<smiles>Cn1cc(-c2ccc3c(c2)CCN3C(=O)Cc2cccc(C(F)(F)F)c2)c2c(N)ncnc21</smiles><smiles>Cc1ccc(Nc2nc(-c3cc(-c4ccccc4)no3)cs2)nc1</smiles><smiles>c1ccc2cc(Nc3nc(-c4cc5ccccc5o4)cs3)ncc2c1</smiles><smiles>Cc1cccc(Nc2nc(-c3cc4ccccc4o3)cs2)n1</smiles>

Figure 5. Prion ligands: 40 (E)-5-(4-(2-(pyridin-4-ylmethylene)hydrazinyl)phenyl)oxazole; 41 N,N'-(methylenebis (4,1-phenylene))bis(2-(pyrrolidin-1-yl)acetamide); $42 \mathrm{~N}$-(4methylpyridin-2-yl)-4-(5-(pyridin-2-yl) thiophen-2-yl)thiazol-2-amine; 43 1-(5-(4-amino-7-methyl-7H-pyrrolo [2,3-d]pyrimidin-5-yl)indolin-1-yl)-2-(3-(trifluoromethyl) phenyl) ethan-1-one; $44 \mathrm{~N}$-(isoquinolin-3-yl)-4-(pyridin-4-yl) thiazol-2-amine; $45 \mathrm{~N}$-(5-methylpyridin-2-yl)-4-(3-phenylisoxazol-5-yl) thiazol-2-amine; 46 4-(3,4-dimethoxy-phenyl)-N-(isoquinoline-3-yl) thiazol-2-amine; 474-(benzofuran-2-yl)-N-(isoquinoline-3-yl)thia-zol-2amine; 48 4-([1,1'-biphenyl]-4-yl)-N-(6-methylpyridin-2-yl)thiazol-2-amine; 49 4-(benzofuran-2-yl)-N-(6-methylpyridin-2-yl) thiazol-2-amine.

pa [Figure 6, (53)], a piperazine-linked bis-acridine, showed in SCN2 cells, a common model of prion infection [156], an ability to decrease markedly the $\operatorname{PrP}{ }^{s c}$ load $\left[\mathrm{EC}_{50}=40 \mathrm{nM}\right)$ and confirmed the presumption of enhanced efficacy in inhibition of $\mathrm{PrP}^{s c}$ replication with bivalent compounds. Moreover, May et al. [156] could demonstrate that the efficacy of these and similar bivalent drugs depends from the length of the linker. 
<smiles>Cc1cccc(Nc2nc(-c3ccc(-c4cccnc4)cc3)cs2)n1</smiles>

50<smiles>Cc1cccc(Nc2nc(-c3ccc(N4CCOCC4)cc3)cs2)n1</smiles>

52<smiles>Cc1cccc(Nc2nc(-c3ccc(-c4ccncc4)cc3)cs2)n1</smiles>

51<smiles>COc1ccc2nc3ccc(Cl)cc3c(NCCCN3CCN(CCCNc4c5ccc(Cl)cc5nc5ccc(Cl)cc45)CC3)c2c1</smiles>

53

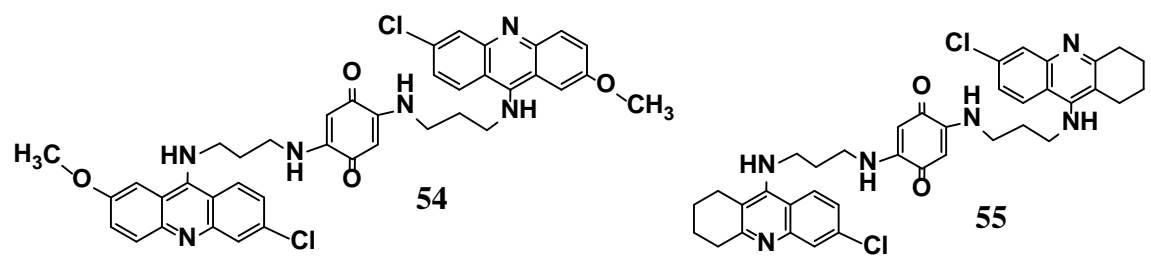<smiles>COc1ccc2nc3cc(Cl)ccc3c(NCCOCCOCCNc3c4cc(Cl)ccc4nc4ccc(OC)cc34)c2c1</smiles>

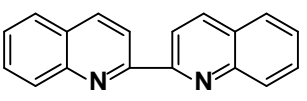

57

56

Figure 6. Prion ligands: $50 \mathrm{~N}$-(6-methylpyridin-2-yl)-4-(4-(pyridin-3-yl)phenyl)thiazolamine; $51 \mathrm{~N}$-(4,6-dimethylpyridin-2-yl)-4-(4-(pyridin-4-yl)phenyl)thiazol-2-amine; 52 $\mathrm{N}$-(6-methyl-pyridin-2-yl)-4-(4-morpholinophenyl)thiazol-2-amine; $53 \mathrm{~N}, \mathrm{~N}$-(piperazine1,4-diylbis(propane-3,1-diyl) bis(6-chloro-2-methoxyacridin-9-amine) 54 2,5-bis ((3((6-chloro-2-methoxy-acridin-9-yl)amino)propyl)amino)cyclohexa-2,5-diene-1,4-dione; 55 (3Z,6Z)-3,6-bis(((3-chloroacridin-9-yl)amino)methylene)piperazine-2,5-dione; $56 \mathrm{~N}, \mathrm{~N}^{\prime}$ ((ethane-1,2-diylbis (oxy)) bis(ethane-2,1-diyl))bis(6-chloro-2-methoxyacridin-9-amine); 57 2,2'-biquinoline.

A drawback of compounds previously investigated in biological models and confirmed to decrease $\operatorname{PrP}^{\mathrm{sc}}$ replication, frequently, was the restriction of the inhibiting effect to the initial period of the infection.

On the other hand, May et al. [156] presumed the piperazine linker provides a steric hindrance for DNA complexation causing a decrease of cytotoxicity.

BiCappa became a starting point of the search for further bivalent antiprion molecules.

Bolognesi et al. [67] [157] introduced diketopiperazine-linked benzoquinonebased compounds which showed high lipophilicity (log $~ 8)$ [Figure 6, (54, 55; (BQ-3 and BQ-6)] but with good inhibitory action on $\operatorname{PrP}^{\mathrm{sc}}$ formation in ScGT1 
cellular systems. A further cellular system employed in antiprion experiments is the pheochromocytoma derived PC12 cells [158].

Several groups of structures with varying spacers to connect the acridine moieties have been proposed [67]. Further proposals by Staderini [67] and Bongarzone et al. [159] were ARC1 [Figure 6, (56)] and ARC2 with an N,N'((ethane-1,2-diylbis(oxy))bis(ethane-2,1-diyl)) spacer as well as several new benzoquinoline derivatives.

\section{Summary and Conclusions}

Structural characterization of aberrant "steric zipper" proteins and descriptions of processes resulting in their assembly to oligomers and larger aggregates have proceeded during the last 20 years and provide today a basis of molecular dynamics studies. This knowledge supplied fundamentals and different approaches to understanding of misfolding as well as its consequences and allowed identification of medicinal chaperones for the inhibition of these processes. On the other hand, paradigms of therapeutic approaches to the cascade and of the time course of neurodegeneration changed [8] [58] [64] and envision today multiple mechanisms of action [17] [66].

Most promising development and release of new tracers with high selectivity can be observed at the moment for tau protein ligands with the focus on pyrroloindole quinolines [68] [128] [135]. $\left[{ }^{18} \mathrm{~F}\right] \mathrm{MK}-6240$-one of the most promising among the scaffolds proposed-is now in phase 1 clinical trial [130].

The new series of isoquinolines as well as the widely investigated fluoro-pyridine T807 are regarded as a starting point to better understanding and monitoring of the mechanisms underlying deterioration of the cognitive function of the brain because tau protein correlates markedly better with decrease of mental abilities than deposits of Aß-aggregates.

Partial volume effects, which can result in underestimation of tracer retention in regions of the brain during destruction, remain issues of methodical improvements [160]. A further problem which can hamper the choice of suitable molecules and pre-clinical investigations of respective new ligands is the different comparability of parameters of lipophilicity and permeability describing bbb delivery of the compounds [161]. Moreover, the diversity of animal models, per se frequently unable to reflect all important features of the pattern of a special conformational disease, remains a drawback for fast recognition of suitable compounds [72] [147].

Several promising proposals of Aß binding molecules with enhanced selectivity have been released. Among these, the aryl oxazole MK 3328 [86]; the benzoxazole $\left[{ }^{18} \mathrm{~F}\right] \mathrm{FACT}[120]$ and the imidazothiazole $\left[{ }^{18} \mathrm{~F}\right]$ FIBT $[121]$ are also candidates for PET imaging in neurodegenerative diseases. The improvement in the kinetics of accumulation in grey matter and reduced uptake in white matter in comparison to florbetaben is a progress for $A ß$ imaging.

The most intense challenges, however, are ligands for $\alpha$-synuclein which can provide access to components of Lewy bodies and potentially improved differen- 
tial diagnosis of Parkinson's and related diseases using PET. The proposals by Bagchi et al. [20] provide potential lead structures. However, neither pharmacodynamics nor pharmacokinetic prerequisites are sufficient at the moment for the usage as a tool in brain PET imaging. On the other hand, lead structures with lower molecular weight and dual specificity binding to prion protein as well as to $\alpha$-synuclein could open the gate not only for improved therapy but also for imaging in Parkinson disease and related disorders [147].

The general statement by Cummings [162] [163] that until today some candidates entered clinical trial, but since approval of memantine in 2003 no further candidate has completed a phase 3 trial, is attenuated for the diagnostic point of view by phase 3 studies presented for florbetaben and florbetapir [65] [113] [116] [163] [164].

Differentiation between patients severely threatened by late-onset $\mathrm{AD}$ and individuals with mild cognitive deficits, but without a later shift to severe dementia, would be a helpful diagnostic contribution by PET and would allow early support and potential therapies to patients at risk of inability to manage their daily life.

\section{Acknowledgements}

The author thanks Pr. Bernd Neumaier for the kind support. This paper is dedicated to Pr. Syed M. Qaim, Jülich, on the occasion of his $75^{\text {th }}$ birthday.

\section{References}

[1] Carrell, R.W. and Lomas, D.A. (1997) Conformational Disease. Lancet, 350, 134138. https://doi.org/10.1016/S0140-6736(97)02073-4

[2] Carrell, R.W. and Gooptu, B. (1998) Conformational Changes and Disease-Serpins, Prions and Alzheimer's. Current Opinion in Structural Biology, 8, 799-809. https://doi.org/10.1016/S0959-440X(98)80101-2

[3] Soto, C. (2003) Unfolding the Role of Protein Misfolding in Neurodegenerative Diseases. Nature Reviews Neuroscience, 4, 49-60. https://doi.org/10.1038/nrn1007

[4] Sipe, J.D., Benson, M.D., Buxbaum, J.N., Ikeda, S-I., Merlini, G., Saraiva, J.M. and Westermark, P. (2014) Nomenclature 2014: Amyloid Fibril Proteins and Clinical Classification of the Amyloidosis. Amyloid, 21, 221-224. https://doi.org/10.3109/13506129.2014.964858

[5] Lomas, D.A. and Carrell, R.W. (2002) Serpinopathies and the Conformational Dementias. Nature Reviews Genetics, 3, 759-768. https://doi.org/10.1038/nrg907

[6] Mahadeva, R. and Lomas, D.A. (1998) $\alpha 1$-Antitrypsin Deficiency, Cirrhosis and Emphysema. Thorax, 53, 501-505. https://doi.org/10.1136/thx.53.6.501

[7] Potempa, J., Korzus, E. and Travis, J. (1994) The Serpin Superfamily of Proteinase Inhibitors: Structure, Function and Regulation. Journal of Biological Chemistry, 269, 15957-15960.

[8] Breydo, L., Wu, J.W. and Uversky, V.N. (2012) $\alpha$-Synuclein Misfolding and Parkinson Disease. $B B A, \mathbf{1 8 2 2}, 261-285$.

[9] Stefani, M. and Dobson, C.M. (2003) Protein Aggregation and Aggregate Toxicity: New Insights into Protein Folding, Misfolding Diseases and Biological Evolution. Journal of Molecular Medicine, 81, 678-699. 
https://doi.org/10.1007/s00109-003-0464-5

[10] Mandelkow, E.-M. and Mandelkow, E. (2012) Biochemistry and Cell Biology of Tau Protein in Neurofibrillar Degeneration. Cold Spring Harbor Perspectives in Medicine, 2, a006247, $26 \mathrm{p}$.

[11] Wang, Y. and Mandelkow, E. (2016) Tau in Physiology and Pathology. Nature Reviews, 17, 5-21.

[12] Aguzzi, A. and Callela, A.M. (2009) Prions: Protein Aggregation and Infectious Disease. Physiological Reviews, 89, 1105-1152.

https://doi.org/10.1152/physrev.00006.2009

[13] Carrell, R.W. and Lomas, D.A. (2002) a1-Antitrypsin-Deficiency. New England Journal of Medicine, 346, 45-53. https://doi.org/10.1056/NEJMra010772

[14] Jucker, M. and Walker, L.C. (2013) Self-Propagation of Pathogenic Protein Aggregation in Neurodegenerative Diseases. Nature, 501, 45-51. https://doi.org/10.1038/nature12481

[15] Pertinhez, T.A., Bouchard, M., Tomlinson, E.J., Wain, R., Ferguson, S.J., Dobson, C.M. and Smith, L.J. (2001) Amyloid Fibril Formation by a Helical Cytochrome. FEBS Letters, 495, 184-186. https://doi.org/10.1016/S0014-5793(01)02384-5

[16] Sablon-Carrazana, M., Fernandez, I., Bencomo, A., Lara-Martinez, R., Rivera-Marrero, S., Dominguez, G., Perez-Perera, R., Jimenez-Garcia, L.F., Altamirano-Bustamante, N.F., Diaz-Delgado, M., Vedrenne, F., Rivillas-Acevedo, L., Pasten-Hidalgo, K., de Lourde Segura-Valdez, M., Islas-andradre, S., Garrido-Magana, E., Perera-Pintado, A., Prats-Capote, A., Rodriguez-Tanty, C. and Altamirano-Bustamante, M.M. (2015) Drug Development in Conformational Diseases: A Novel Family of Chemical Chaperons that Bind and Stabilize Several Polymorphic Amyloid Structures. PLOS One, 10, e0135292. https://doi.org/10.1371/journal.pone.0135292

[17] Dani, M., Brooks, D.J. and Edison, P. (2016) Tau Imaging in Neurodegenerative Diseases. European Journal of Nuclear Medicine and Molecular Imaging, 43, 11391150. http://dx.doi.org/10.1007/s00259-015-3231-2

[18] Oukoloff, K, Cieslikiewicz-Bouet, M., Chao, S., Da Costa Branquinho, E., Bouteiller, C., Ludovic, J. and Renard, P.-Y. (2015) PET and SPECT Radiotracers for Alzheimer's Disease. Current Medicinal Chemistry, 22, 3278-3304. https://doi.org/10.2174/0929867322666150805094645

[19] Ishii, K. (2014) PET Approaches for Diagnosis of Dementia. American Journal of Neuroradiology, 9 p. (Online)

[20] Bagchi, D.P., Yu, L., Permutter, J.S., Xu, J., Mach, R.H., Tu, Z. and Kotzbauer, P.T. (2013) Binding of the Radioligand SIL23 to Alpha Synuclein Fibrils in Parkinson Disease Brain Tissue Establishes Feasiblity and Screening Approaches for Developing a Parkinson Disease Imaging Agent. PLOS One, 8, e55031. https://doi.org/10.1371/journal.pone.0055031

[21] Ghaemmaghami, S., May, B.C.H., Renslo, A.R. and Prusiner, S.B. (2010) Discovery of 2 Aminothiazoles as Potent Anti-Prion Compounds. Journal of Virology, 84, 3408-3412. https://doi.org/10.1128/JVI.02145-09

[22] Goldschmidt, L., Teng, P.K., Riek, R. and Eisenberg, D. (2010) Identifying the Amylome, Proteins Capable Forming Amyloid-Like Fibrils. PNAS, 107, 3487-3492. https://doi.org/10.1073/pnas.0915166107

[23] Gidalevitz, T., Kikis, E.A. and Morimoto, R.I. (2010) A Cellular Perspective on Conformational Disease: the Role of Genetic Background and Proteostasis Networks. Current Opinion in Structural Biology, 20, 23-32.

https://doi.org/10.1016/j.sbi.2009.11.001 
[24] Balbirnie, M., Grothe, R. and Eisenberg, D. (2001) An Amyloid-Forming Peptide from the Yeast Prion Sup 35 Reveals a Dehydrated $\beta$.Sheet Structure for Amyloid. Proceedings of the National Academy of Sciences, 98, 2375-2380. https://doi.org/10.1073/pnas.041617698

[25] Sawaya, M.R., Sambashivan, S., Nelson, R., Ivanova, M.L., Sievers, S.A., Balbiernie, M., Wiltius, J.J.W., McFarlane, H.T., Madsen, A.O., Riekel, C. and Eisenberg, D. (2007) Atomic Structure of Amyloid Cross- $\beta$-Spine Reveal Varied Steric Zippers. Nature, 447, 447-457. https://doi.org/10.1038/nature05695

[26] Jarrett, J.T. and Lansbury Jr., P.T. (1993) Seeding “One Dimensional Crystallization" of Amyloid a Pathogenic Mechanism of Alzheimer's Disease and Scrapie? Cell, 73, 1055-1058. https://doi.org/10.1016/0092-8674(93)90635-4

[27] Baker, H.F., Ridley, R.M., Duchen, L.W., Crow, T.J. and Bruton, C.J. (1993) Evidence for the Transmission of Cerebral B-Amyloidosis to Primates. International Journal of Experimental Pathology, 74, 441-454.

[28] Aguzzi, A., Barres, B.A. and Bennett, M.L. (2013) Microglia: Scapegoat, Saboteur, or Something Else. Science, 339, 156-161. https://doi.org/10.1126/science.1227901

[29] Nelson, R., Sawaya, M., Balbiernie, M., Madsen, A., Riekel, C., Grothe, R. and Eisenberg, D. (2005) Structure of the Cross-Beta Spine of Amyloid-Like Fibrils. Nature, 435, 773-778. https://doi.org/10.1038/nature03680

[30] Rosetti, G., Bongarzone, S. and Carloni, P. (2013) Computational Studies on the Prion Proteins. Current Topics in Medicinal Chemistry, 13, 1-13. https://doi.org/10.2174/15680266113136660170

[31] Salloway, S., Mintzer, J., Weiner, M.F. and Cummings, J.L. (2008) Disease-Modifying Therapies in Alzheimer's Disease. Alzheimer's and Dementia, 4, 65-79. https://doi.org/10.1016/j.jalz.2007.10.001

[32] Saba Sheikh, S., Haque, E. and Mir, S.S. (2013) Neurodegenerative Diseases: Multifactorial Conformational Diseases and Their Therapeutic Interventions. Journal of Neurodegenerative Diseases, 2013, Article ID: 563481, 8 p.

[33] Haass, C. and Selkoe, D.J. (2007) Soluble Protein Oligomers in Neurodegeneration: Lessons from the Alzheimer's Amyloid ß-Peptide. Nature Reviews/Molecular Cell Biology, 8, 101-112. https://doi.org/10.1038/nrm2101

[34] Mallucci, G., Dickinson, A., Linehan, J., Klohn, P.C., Brandner, S. and Collinge, J. (2003) Depleting Neuronal PrP Prion Infection Prevents Disease and Reverses Spongiosis. Science, 302, 871-874. https://doi.org/10.1126/science.1090187

[35] Mallucci, G.R. (2009) Prion Neurodegeneration: Starts and Stops at the Synapse. Prion, 3, 195-201. https://doi.org/10.4161/pri.3.4.9981

[36] Jucker, M. (2010) The Benefits and Limitations of Animal Models for Translational Research in Neurodegenerative Diseases. Nature Medicine, 16, 1210-1214. https://doi.org/10.1038/nm.2224

[37] Dubois, B., Feldman, H.H., Jacova, C., Cummings, J.L., DeKosky, S.T., BarbergerGateau, P., Delacourte, A., Frisoni, G., Fox, N.C., Galasko, D., Gauthier, S., Hampel, H., Jicha, G.A., Meguro, K., O’Brien, J., Pasquier, F., Robert, P., Salloway, S., Sarazin, M., de Souza, L.C., Stern, Y., Visser, P.J. and Scheltens, P. (2011) Revising the Definition of Alzheimer's Disease: a New Lexicon. Lancet Neurology, 9, 1118-1127. https://doi.org/10.1016/S1474-4422(10)70223-4

[38] Braak, H. and Braak, E. (1995) Staging of Alzheimer's Disease-Related Neurofibrillary Changes. Neurobiology of Aging, 16, 271-284.

https://doi.org/10.1016/0197-4580(95)00021-6

[39] Braak, H., Braak, E., Bohl, J. and Reintjes, R. (1996) Age, Neurofibrillary Changes 
and B Amyloid and the Onset of Alzheimers Disease. Neuroscience Letters, 210, 8790. https://doi.org/10.1016/0304-3940(96)12668-9

[40] McQuaid, S., Allen, I.V., McMahon, J. and Kirk. J. (1994) Association of Measles Virus with Neurofibrillary Tangles in Subacute Sclerosing Panencephalitis: a Combined in situ Hybridization and Immunocytochemical Investigation. Neuropathology and Applied Neurobiology, 20, 103-110. https://doi.org/10.1111/j.1365-2990.1994.tb01168.x

[41] Miklossy, J. (2015) Historic Evidence to Support a Causal Relationship between Spirochetal Infections and Alzheimer's Disease. Frontiers in Aging Neuroscience. 7, Article 46, 12.

[42] Ball, M.J., Lukiw, W.J., Kammerman, E.M. and Hill, J.M. (2013) Intracerebral Propagation of Alzheimer's Disease: Strengthening Evidence of a Herpes Simplex Virus Etiology. Alzheimer's Dementia, 9, 169-175.

https://doi.org/10.1016/j.jalz.2012.07.005

[43] Itzhaki, R.F., Lathe, R., Balin, B.J., Ball, M.J., Bearer, E.L., Braak, H., Bullido, M.J., Clerici, M., Cosby, S.L., Del Tredici, K., Field, H., Fulop, T., Grassi, C., Griffin, W.S.T., Haas, J., Hudson, A.P., Kamer, A.R., Kell, D.B., Licastro, F., Letenneur, L., Lövheim, H., Mancuso, R., Miklossy, J., Otth, C., Palamara, A.T., Perry, G., Preston, C., Pretorius, E., Strandberg, T., Tabet, N., Taylor-Robinson, S.D. and WhittumHiudson, J.A. (2016) Microbes and Alzheimer's Disease. Journal of Alzheimer's Disease, 51, 979-984. https://doi.org/10.3233/JAD-160152

[44] Dawkins, E. and Small, D.H. (2014) Insights into the Physiological Function of B-Amyloid Precursors: Beyond Alzheimer's Disease. Journal of Neurochemistry, 129, 756-769. https://doi.org/10.1111/jnc.12675

[45] Pearson, H.A. and Peers, C. (2006) Physiological Roles for Amyloid B Peptides. The Journal of Physiology, 5751, 5-10. https://doi.org/10.1113/jphysiol.2006.111203

[46] Maji, S.K., Perrin, M.H., Sawaya, M.R., Jessberger, S., Vadodaria, K., Rissman, R.A., Singru, P.S., Nilsson, K.P., Simon, R., Schubert, D., Eisenberg, D., Rivier, J., Sawchenko, P., Vale, W. and Riek, R. (2009) Functional Amyloids as Natural Storage of Peptide Hormones Pituitary Secretory Granula. Science, 325, 328-332. https://doi.org/10.1126/science.1173155

[47] Fowler, D.M., Koulov, A.V., Balch, B.E. and Kelly, J.W. (2007) Functional Amyloid -From Bacteria to Humans. TIBS, 32, 217-223. https://doi.org/10.1016/j.tibs.2007.03.003

[48] Taylor, J.D. and Matthews, S.J. (2015) New Insight into the Molecular Control of Bacterial Functional Amyloids. Frontiers in Cellular and Infection Microbiology, 5, Article 33, 7 p.

[49] Jaworski, T., Dewachter, I., Seymour, C.M., Borghgraef, P., Devijver, H., Kügler, S. and van Leuven, F. (2010) Alzheimer's Disease: Old Problem, New Views from Transgenic to Viral Models. Biochimica Biophysica Acta, 1802, 808-818. https://doi.org/10.1016/j.bbadis.2010.03.005

[50] Trudler, D., Farfara, D. and Frenkel, D. (2010) Toll-Like Receptors Expression and Signaling in Glia Cells in Neuro-Amygdalogenic Diseases: Toward Future Therapeutic Applications. Mediators of Inflammation, Article ID: 497987, $12 \mathrm{p}$.

[51] Heneka, M.T., Carson M.J., El Khoury J., Landreth, G.E., Brosseron , F., Feinstein, D.L., Jacobs, A.H., Wyss-Coray, T., Vitorica J., Ransohoff, R.M., Herrup, K., Frautschy, S., Finsen, B., Brown , G.C., Verkhratsky, A., Yamanaka, K., Koistinaho, J., Latz, E., Halle, A., Petzold, G.C., Town, T., Morgan , D., Shinohara, M.L., Perry, V.H., Holmes, C., Bazan, N.G., Brooks , D.J., Hunot, S., Joseph, B., Deigendesch, N., Karaschuk, O., Boddeke, E., Dinarello, C.A., Breitner, J.C., Cole, G.M., Golenbock, 
D.T. and Kummer, M.P. (2015) Neuroinflammation in Alzheimer's Disease. The Lancet Neurology, 14, 388-405. https://doi.org/10.1016/S1474-4422(15)70016-5

[52] Swerdlow, R.H., Burns, J.M. and Khan, S.M. (2014) The Alzheimer's Disease Mitochondrial Cascade Hypothesis: Progress and Perspectives. Biochimica Biophysica Acta, 1842, 1219-1231. https://doi.org/10.1016/j.bbadis.2013.09.010

[53] Swerdlow, R.H. and Khan, S.M. (2004) A Mitochondrial Cascade Hypothesis for Sporadic Alzheimer's Disease. Medical Hypotheses, 63, 8-20. https://doi.org/10.1016/j.mehy.2003.12.045

[54] Howlett, G.J. and Moore, K.J. (2006) Untangling the Role of Amyloid in Atherosclerosis. Current Opinions in Lipidology, 17, 541-547. https://doi.org/10.1097/01.mol.0000245260.63505.4f

[55] De la Torre, J.C. (2013) Vascular Risk Factors: A Ticking Time Bomb to Alzheimer's Disease. American Journal of Alzheimer's Disease Other Dementia, 28, 551 559. https://doi.org/10.1177/1533317513494457

[56] Iqbal, K., Liu, F. and Gong, C.-X. (2016) Tau and Neurodegenerative Disease: The Story so Far. Nature Reviews, 12, 15-27.

[57] Fodero-Tavoletti, M.T., Brockschnieder, D., Villemagne, V.L., Martin, L., Connor, A.R., Thiele, A., Berndt, M., McLean, C.A., Krause, S., Rowe, C.C., Masters, C.L., Dinkelborg, L., Dyrks, T. and Cappai, R. (2012) In Vitro Characterization of [18F]-florbetaben, an Abeta Imaging Radiotracer. Nuclear Medicine and Biology, 39, 1042-1048. https://doi.org/10.1016/j.nucmedbio.2012.03.001

[58] Melki, R. (2015) Role of Alpha-Synuclein Strains in Synucleinopathies, Similarities with other Neurodegenerative Diseases. Journal of Parkinson's Disease, 5, 217-227. https://doi.org/10.3233/JPD-150543

[59] Bucciantini, M., Nosi, D., Forzan, M., Russo, E., Calamai, M., Pieri. L, Formigli, L., Quercioli, F., Soria, S., Pavone, F., Savistchenko, J., Melki, R. and Stefani, M. (2012) Toxic Effects of Amyloid Fibrils on Cell Membranes. FASEB Journal, 26,818-831. https://doi.org/10.1096/fj.11-189381

[60] Berthelot, K., Cullin, C. and Lecomte, S. (2013) What Does Make an Amyloid Toxic: Morphology, Structure or Interaction with Membrane? Biochimie, 95, 12-19. https://doi.org/10.1016/j.biochi.2012.07.011

[61] Cecchi, C. and Stefani, M. (2013) The Amyloid Cell-Membrane System. The Interplay between the Biophysical Features of Oligomeric/Fibrils and Cell Membrane Defines Amyloid Toxicity. Biophysical Chemistry, 182, 30-43. https://doi.org/10.1016/j.bpc.2013.06.003

[62] Jiang, H., Wang, X., Hunang, L., Su, T. and Li, X. (2011) Benzenediol Berberine Hybrides: Multifunctional Agents for Alzheimer's Disease. Bioorganic \& Medicinal Chemistry, 19, 7228-72235. https://doi.org/10.1016/j.bmc.2011.09.040

[63] Durairajan, S.S.K., Liu, L.-F., Lu, J.-H., Chen, L.-L., Yuan, Q., Chung, S.K., Huang, L., Li, X.-S., Huang, J.-D. and Li, M. (2012) Berberine Ameliorates B-Amyloid Pathology, Gliosis and Cognitive Impairment in an Alzheimer's Disease Transgenic Mouse Model. Neurobiology of Aging, 33, 2903-2919. https://doi.org/10.1016/j.neurobiolaging.2012.02.016

[64] Yiannopoulou, K.G. and Papageorgiou, S. (2013) Current and Future Treatments for Alzheimer's Disease. Therapeutic Advances in Neurological Disorders, 6, 19-33. https://doi.org/10.1177/1756285612461679

[65] Bolognesi, M.L., Gandini, A., Prati, F. and Uliassi, E. (2016) From Companion Diagnostics to Theranostics: A New Avenue for Alzheimer's Disease? Journal of Medicinal Chemistry, 59, 7759-7770. https://doi.org/10.1021/acs.jmedchem.6b00151 
[66] Aulic, S., Bolognesi, M.L. and Legname, G. (2013) Small Molecule Theranostic Probes: A Promising Future in Neurodegenerative Diseases. International Journal of Cell Biology, 2013, Article ID: 150952. https://doi.org/10.1155/2013/150952

[67] Staderini, M. (2015) New Molecular Scaffolds for Antineurodegenerative Drug Discovery. PhD Thesis, Universidad Complutense de Madrid, Madrid.

[68] Jovalekic, A., Koglin, N., Mueller, A. and Stephens, A.W. (2016) New Protein Deposition Tracers in the Pipeline. EJNMMI Radiopharmacy and Chemistry, 1, 12 p.

[69] Arora, A. and Bhagat, N. (2016) Insight into the Molecular Imaging of Alzheimer's Disease. International Journal of Biomedical Imaging, 2016, Article ID: 7462014, 17 p.

[70] Villemagne, V.L. and Okamura, N. (2014) In Vivo Tau Imaging: Obstacles and Progress. Alzheimer's \& Dementia, 10, S254-S264. https://doi.org/10.1016/j.jalz.2014.04.013

[71] Truong, P.M., Viet, M.H., Nguyen, P.H., Hu, C.-K. and Li, S.M. (2014) Effect of Taiwan Mutation (D7H) on Structures of Amyloid- 3 Peptides: Replica Exchange Molecular Dynamics Study. Journal of Physical Chemistry, 118, 8972-8981. https://doi.org/10.1021/jp503652s

[72] Epis, R., Gardoni, F., Gardoni, F., Marcello, E., Genazzani, A., Canonico, P.L. and Di Luca, M. (2010) Searching for New Animal Models of Alzheimer's Disease. European Journal of Pharmacology, 626, 57-63. https://doi.org/10.1016/j.ejphar.2009.10.020

[73] Galimberti, D. and Scarpini, E. (2010) Treatment of Alzheimer's Disease: Symptomatic and Disease-Modifying Approaches. Current Aging Science, 3, 46-56. https://doi.org/10.2174/1874609811003010046

[74] Liu, H.-L., Wu, C.-C., Zhao, J.-H., Liu, Y.-F., Huang, C.-H., Fang, H.-W. and Ho, Y. (2007) Insights into Conformational Changes of Several Human Lysozyme Variants Associated with Hereditary Associated Amyloidosis. Biotechnology Progress, 23, 246-254. https://doi.org/10.1021/bp060264a

[75] Ossenkoppele, R., Schonhaut, D.R., Schöll, M., Lockhart, S.N., Ayakta, N., Baker, S.L., O’Neil, J.P., Janabi, M., Lazaris, A., Cantwell, A., Vogel, J., Santos, M., Miller, Z.A., Bettcher, B.M., Vossel, K.A., Kramer. J.H., Gorno-Tempini, M.L., Miller, B.L., Jagust, W.J. and Rabinovici, G.D. (2016) Tau PET Patterns Mirror Clinical and Neuroanatomical Variability in Alzheimer's Disease. Brain, 139, 1551-1567. https://doi.org/10.1093/brain/aww027

[76] Small, G.W., Kepe, V., Ercolim, L.M., Siddarth, P., Bookheimer, S.Y., Miller, K.J., Lavretsky, H., Burggren, A.C.,Cole, G.M., Vinters, H.V., Thompson, P.M., Huang, S.C., Satyamurthy, N., Phelps, M.E. and Barrio, J.R. (2006) PET of Brain Amyloid and Tau in Mild Cognitive Impairment. New England Journal of Medicine, 355, 2652-2663. https://doi.org/10.1056/NEJMoa054625

[77] Jahn, T.R., Tennent, J.A. and Radford, S.E.A. (2008) Common B Sheet Architecture Underlies In Vitro and In Vivo ß2-Microglobulin Amyloid Fibrils. Journal of Biological Chemistry, 283, 17279-17286. https://doi.org/10.1074/jbc.M710351200

[78] Bennhold, H. (1922) Specific Staining of Amyloid by Congo Red. Münchener Medizinische Wochenschrift, 69, 1537-1538.

[79] Divry, P. (1927) Etude Histochemique de Plaques Seniles. Journal Belge De Neurologie Et De Psychiatrie, 27, 643-657.

[80] Khurana, R., Uversky, V.N., Nielsen, L. and Fink, A.L. (2001) Is Congo Red an Amyloid-Specific Dye? Journal Biological Chemistry, 276, 22715-22721. https://doi.org/10.1074/jbc.M011499200 
[81] Puchtler, H., Sweat, F. and Levine, M.J. (1962) On the Binding of Congo Red by Amyloid. Journal of Histochemistry \& Cytochemistry, 10, 355-363. https://doi.org/10.1177/10.3.355

[82] Brier, M.R., Gordon, B., Friedrichsen, K., McCarthy, J., Stern, A., Christensen, J., Owen, C., Aldea, P., Yi, S., Hassenstab, J., Cairns, N.J., Holtzman, D.M., Fagan, A.M., Morris, J.C., Benzinger, T.L.S. and Ances, B.M. (2016)Tau and Aß Imaging, CSF Measures, and Cognition in Alzheimer's Disease. Science Translational Medicine, 6, 338ra66.

[83] Edwards, R.A. and Woody, R.W. (1977) Induced Circular Dichroism as a Probe of Cibacron Blue and Congo Red Bound to Dehydrogenases. Biochemical and Biophysical Research Communications, 79, 470-476. https://doi.org/10.1016/0006-291X(77)90181-4

[84] Bancroft, J.D. and Gamble, M. (2008) Theory and Practice of histological Techniques. Elsevier, Churchill Livingston.

[85] Wu, C., Scott, J. and Shea, J.-E. (2012) Binding of Congo Red to Amyloid Protofibrils of the Alzheimer Aß 9-40 Peptide Probed by Molecular Dynamic Simulations. Biophysical Journal, 103, 550-557. https://doi.org/10.1016/j.bpj.2012.07.008

[86] Lendel, C., Bolognesi, B., Wahlström, A., Dobson, C.M. and Gräslund, A. (2010) Detergent-Like Interaction of Congo Red with the Amyloid B Peptide. Biochemistry, 49, 1358-1360. https://doi.org/10.1021/bi902005t

[87] Reinke, A.A. and Gestwicki, J.E.. (2011) Insight into Amyloid Structure Using Chemical Probes. Chemical Biology \& Drug Design, 77, 399-411.

https://doi.org/10.1111/j.1747-0285.2011.01110.x

[88] Klunk, W.E., Lopresti, B.J., Ikonomovic, M.D., Levterov, I.M., Koldamova, R.P., Abrahamson, E.E., Debnath, M.I., Holt, D.B., Huang, G.-F., Shao, L., DeKosky, S.T., Price, J.C. and Matthis, C.A. (2005) Binding of the Positron Emission Tomography Tracer Pittsburgh Compound-B Reflects the Amount of Amyloid $\beta$ in Alzheimer's Disease Brain but not in Transgenic Mouse Brain. Journal of Neuroscience, 25, 10598-10606. https://doi.org/10.1523/JNEUROSCI.2990-05.2005

[89] Rokka, J., Snellman, A., Zona, C., La Ferla, B., Nicotra, F., Salmona, M., Forloni, G., Haaparanta-Solin, M., Rinne, J.O. and Solin, O. (2014) Synthesis and Evaluation of a ${ }^{18} \mathrm{~F}$-Curcumin Derivative for Amyloid Plaque Imaging. Bioorganic \& Medicinal Chemistry, 22, 2753-2762. https://doi.org/10.1016/j.bmc.2014.03.010

[90] Harrison, S.T., Mulhearn, J., Wolkenberg, S.E., Miller, P.J., O’Malley, S.S., Zeng ,Z., Williams, D.L., Hostetler, E.D., Sanabria-Bohorquez, S., Gammage, L., Fan, H., Sur, C., Culberson, J.C., Hargreaves, R.J., Cook, J.J., Hartman, G.D. and Barrow, J.C. (2011) Synthesis and Evaluation of 5-Fluoro-2 Aryloxazolo[5,4-b]Pyridines as $B$ Amyloid PET Ligands and Identification of MK-3328. ACS Medicinal Chemistry Letters, 2, 498-502. https://doi.org/10.1021/ml200018n

[91] Ni, R., Gillberg, P.-G., Bergfors, A., Marutle, A. and Nordberg, A. (2013) Amyloid Tracers Detect Multiple Binding Sites in Alzheimer's Disease Brain Tissue. Brain, 136, 2217-2227. https://doi.org/10.1093/brain/awt142

[92] Hostetler, E.D., Sanabria-Bohorquez, S., Fan, H., Zebg, Z., Gammage, L., Miller, P., O’Malley, S., Connolly, B., Mulhearn, J., Harrison, S.T., Wolkenberg, S.E., Barrow, J.C., Williams, D.L., Hargreaves, R.J., Sur, C. and Cook, J.J. (2011) $\left[{ }^{18}\right.$ F]Fluoroazabezoxazoles as Potential Amyloid Plaque PET Tracers: Synthesis and in Vivo Evaluation in Rhesus Monkeys. Nuclear Medicine and Biology, 38, 1193-1203.

https://doi.org/10.1016/j.nucmedbio.2011.04.004

[93] Pissarek, M. and Disko, U. (2013) Non-Peptide Ligands in the Characterization of 
Peptide Receptors at the Interface between Neuroendocrine and Mental Diseases. WJNS, 3, 100-125. https://doi.org/10.4236/wjns.2013.32014

[94] Lipinski, C.A., Lombardo, F., Dominy, B.W. and Feeney, P.J. (1997) Experimental and Computational Approaches to Estimate Solubility and Permeability in Drug discovery and Development Settings. Advanced Drug Delivery Reviews, 23, 3-25. https://doi.org/10.1016/S0169-409X(96)00423-1

[95] Harada, R., Okamura, N., Furumoto, S., Tago, T., Maruyama, M., Higuchi, M., Yoshikawa, T., Arai, H., Iwata, R., Kudo, Y. and Yanai, K. (2013) Comparison of the Binding Characteristics of $\left[{ }^{18} \mathrm{~F}\right] \mathrm{THK}-523$ and other Amyloid Imaging Tracers to Alzheimer's Disease Pathology. European Journal of Nuclear Medicine and Molecular Imaging, 40, 125-132. https://doi.org/10.1007/s00259-012-2261-2

[96] Shoghi-Jadid, K., Small, G.W., Agdeppa, E.D., Kepe, V., Ercoli, L.M., Siddarth, P., Read, S., Sathyamurthy, N., Petric, A., Huang, S.-C. and Barrio, J.R. (2002) Localization of Neurofibrillary Tangles and beta-Amyloid Plaques in the Brains of Living Patients with Alzheimer Disease. American Journal of Geriatric Psychiatry, 10, 2435. https://doi.org/10.1097/00019442-200201000-00004

[97] Henriksen, G., Hauser, A.I., Westwell, A.D., Yousefi, B.H., Schwaiger, M., Drzega, A. and Wester, H.-J. (2007) Metabolic Stabilized Benzothiazoles for Imaging of Amyloid Plaques. Journal of Medicinal Chemistry, 50, 1087-1089. https://doi.org/10.1021/jm061466g

[98] Neumaier, B., Deisenhofer, S., Sommer, C., Solbach, C., Reske, S.N. and Mottaghy, F. (2010) Synthesis and Evaluation of ${ }^{18}$ F-Fluoroethylated Benzothiazole Derivatives for Imaging of Amyloid Plaques in Alzheimer's Disease. Applied Radiation and Isotopes, 68, 1066-1072. https://doi.org/10.1016/j.apradiso.2009.12.044

[99] Barrio, J.R., Small, G.W., Wong, K.-P., Huang, S.-C., Liu, J., Merrill, D.A., Giza, C.C., Fitzsimmons, R.P., Omalu, B., Bailes, J. and Kepe, V. (2015) In Vivo Characterization of Chronic Traumatic Encephalopathy Using $\left[{ }^{18} \mathrm{~F}\right]$ FDDNP PET Brain Imaging. PNAS, 112, E2039-E2047. https://doi.org/10.1073/pnas.1409952112

[100] Agdeppa, E.D., Kepe, V., Liu, J., Flores-Torres, S., Satyamurthy, N. and Petric, A. (2001) Binding Characteristics of Radiofluorinated 6-Dialkylamino-2-Naphtylethyliden Derivatives as Positron Emission Tomography Imaging Probes for Beta Amyloid Plaques in Alzheimer's Disease. Journal of Neuroscience, 21, RC 189: 1-5.

[101] Maruyuma, M., Shimada, H., Suhara, T., Shinoto, H., Maeda, J., Zhang, M.-R., Trojanowski, J.Q., Lee, V.M.-Y., Masomoto, K., Takano, H., Sahara, N., Iwata, N., Okamura, N., Furumoto, S., Kudo, Y., Chang, Q., Saido, T.C., Takashima, A., Lewis, J., Jang, M.-K., Aoki, I., Ito, H. and Higuchi, M. (2013) Imaging of Tau Pathology in a Tauopathy Mouse Model and in Alzheimer Patients Compared to Normal Controls. Neuron, 79, 1094-1108. https://doi.org/10.1016/j.neuron.2013.07.037

[102] Klunk, W.E., Engler, H., Nordberg, A., Wang, Y., Blomqvist, G., Holt, D.P., Bergström, M., Savitchera, I., Huang, G.-F., Estrada, S., Ausen, B., Debnath, M.L., Barletta, J., Price, J.C., Sandell, J., Lopresti, B.J., Wall, A., Koivisto, P., Antoni, G., Mathis, C.A. and Langström, B.(2004) Imaging Brain Amyloid in Alzheimer's Disease with Pittsburgh Compound-B. Annals of Neurology, 55, 306-319. https://doi.org/10.1002/ana.20009

[103] Klunk, W.E., Wang, J., Huang, G.-F., Debnath, M.L., Holt, D.P., Shao, L., Hamilton, R.L., Ikonomovic, M.D., DeKosky, S.T. and Mathis, C.A. (2003) The Binding of 2-(4-Methylaminopheny)Benzothiazole to Postmortem Brain Homogenates is Dominated by the Amyloid Component. Journal of Neuroscience, 23, 2086-2092.

[104] Kudo, Y., Okamura, N., Furumoto, S., Tashiro, M., Furukawa, K., Maruyuma, M., Itoh, M., Iwata, R., Yanai, K. and Arai, H. (2007) 2-(2-[2-Dimethylaminothiazol-5- 
yl]Ethenyl)-6-(2-[Fluoro]Ethoxy)Benzoxazole: A Novel PET Agent for in Vivo Detection of Defense Amyloid Plaques in Alzheimer's Disease Patients. Journal of Nuclear Medicine, 48, 553-561. https://doi.org/10.2967/jnumed.106.037556

[105] Kepe, V., Moghbel, M.C., Langström, B., Zaidi, H., Vinters, H.V., Huang, S.-C., Satyamurthy, N., Doudet, D., Mishani, E., Cohen, R.M., Holund-Carlsen, P.F., Alavi, A. and Barrio, J.R., (2013) Amyloid- $\beta$ Positron Emission Tomography Imaging Probes: A Critical Review. Journal of Alzheimer's Disease, 36, 613-663.

[106] Wong, D.F., Mogekhar, A.R., Rigamonti, D., Brasic, J.R., Rousset, O., Willis, W., Buckley, C., Smith, A., Gok, B., Sherwin, P. and Grachev, I.D. (2013 ) An in vivo Evaluation of Cerebral Cortical Amyloid with $\left[{ }^{18} \mathrm{~F}\right]$ Flutemetamol Using Positron Emission Tomography Compared with Parietal Biopsy Samples in Living Normal Pressure Hydrocephalus Patients. Molecular Imaging and Biology, 15, 230-237. https://doi.org/10.1007/s11307-012-0583-X

[107] Berndt, U., Stanetty, C., Wanek, T., Kuttner, C., Stanek, J., Berger, M., Bauer, M., Henriksen, G., Wester, H.-J., Karterni, K.H., Angelberger, P. and Noe, C. (2008) Synthesis of a $\left[{ }^{18} \mathrm{~F}\right]$ Fluorobenzothiazole as Potential Amyloid Imaging Agent. Journal of Labelled Compounds and Radiopharmaceuticals, 51, 137-145. https://doi.org/10.1002/jlcr.1476

[108] Zheng, M.-Q., Yin, D.-Z., Qiao, J.-P., Zhang, L. and Wang, Y.-X. (2008a) Syntheses and Evaluation of Fluorinated Benzothiazoleanilines as Potential Tracers for ß-Amyloid Plaques in Alzheimer's Disease. Journal of Fluorine Chemistry, 129, 210-216. https://doi.org/10.1016/j.jfluchem.2007.11.005

[109] Zheng, M.Q., Yin, D.Z., Zhang, L., Lei, B, Cheng, D.-F., Cai, H.-C., Han, Y.-J., Wu, M.-X., Zhang, H. and Wang, J. (2008b) Biologicalcharacters of $\left[{ }^{18} \mathrm{~F}\right] \mathrm{O}-\mathrm{FEt}-\mathrm{PIB}$ in a Rat Model of Alzheimer's Disease Using Micro-PET-Imaging. Acta Pharmacologica Sinica, 29, 548-554. https://doi.org/10.1111/j.1745-7254.2008.00785.x

[110] Nyberg, S., Jörnhagen, M.E., Cselenyi, Z., Halldin, C., Julin, P., Olsson, H., FreundLevi, Y., Andersson, J., Varnas, K., Svensson, S. and Farde, L. (2009) Detection of Amyloid in Alzheimer's Disease with Positron Emission Tomogragphy Using $\left[{ }^{11} \mathrm{C}\right] \mathrm{AZD} 2184$. European Journal of Nuclear Medicine and Molecular Imaging, 36, 1859-1863. https://doi.org/10.1007/s00259-009-1182-1

[111] Verhoeff, N.P., Wilson, A.A., Takeshita, S., Trop, L., Hussey, D., Singh, K., Kung, H.F., Kung, M.P. and Houle, S. (2004) In Vivo Imaging of Alzheimer Disease Beta-Amyloid with $\left[{ }^{11} \mathrm{C}\right] \mathrm{SB}-13$ PET. American Journal of Geriatric Psychiatry, 12, 584-595.

[112] James, O.G., Doraiswamy, P.M. and Borges-Neto, S. (2015) PET Imaging of Tau Pathology in Alzheimer's Disease and Tauopathies. Frontiers in Neurology, 6, Article 38 .

[113] Yang, L., Rieves, D. and Ganley, C. (2012) Brain Amyloid Imaging-FDA Approval of Flobetapir F18 Injection. New England Journal of Medicine, 367, 885-887. https://doi.org/10.1056/NEJMp1208061

[114] Sander, K., Lashley, T., Gami, P., Gendron, T., Lythgoe, M.F., Rohrer, J.D., Schott, J.M., Revesz, T., Fox, N.C. and Arstad, E. (2016) Characterization of Tau Positron Emission Tomography Tracer $\left[{ }^{18} \mathrm{~F}\right] \mathrm{AV}-1451$ Binding to Postmortem Tissue in Alzheimer's Disease, Primary Tauopathies, and Other Dementias. Alzheimer's \& Dementia, 12, 116-1124. https://doi.org/10.1016/j.jalz.2016.01.003

[115] Reiman, E.M., Quiroz, Y.T., Fleisher, A.S., Chen, K., Velez-Pardo, C., Jimenez-DelRi, M., Fagan, A.M., Shah, A.R., Alvarez, S., Arbelaez, A., Girald, M., Acoster-Baena, N., Sperling, R.A., Dickerson, B., Stern, C.E., Tirado, V., Munoz, C., Reiman, R.A. and Huentelman, M. (2012) Brain Imaging and Fluid Biomarker Analysis in 
Young Adults at Genetic Risk for Autosomal Dominant Alzheimer's Disease in the Presenilin 1 E280A Kindred: a Case-Control Study. The Lancet Neurology, 11, 1048-1056. https://doi.org/10.1016/S1474-4422(12)70228-4

[116] Fleisher ,A.S., Chen, K., Quiroz, J.T., Jakimovitch, L.J., Gomez, M.G., Langois, C.M., Langbaum, J.B.S., Ayutyanont, N., Roontiva, A., Tiyyagura, P., Lee, W., Mo, H, Lopez, L., Moreno, S., Acosta-Baena, N., Giraldo, M., Garcia, G., Reiman, R.A., Huentelman, M.J., Kosik, K.S., Tairot, P.N., Lopera, F. and Reiman, E.M. (2012) Florbetapir PET Analysis of Amyloid Aß Deposition in the Presenilin 1 E280a Autosomal Dominant Alzheimer's Disease Kindred: a Cross Sectional Study. Lancet, 11, 10571065. https://doi.org/10.1016/S1474-4422(12)70227-2

[117] Jureus, A., Swahn, B.-M., Sandell, J., Jeppson, F., Johnson, A.F., Johnström, P., Neelissen, J.A.M., Sunnemark, D., Farde, L. and Svensson, S. (2010) Characterization of AZD4694, a Novel Fluorinated Aß Plaque Neuroimaging PET Radioligand. Journal of Neurochemistry, 114, 784-794. https://doi.org/10.1111/j.1471-4159.2010.06812.x

[118] Sabri, O., Seibyl, J., Rowe, C. and Barthel, H. (2015) Beta-Amyloid Imaging with Florbetaben. Clinical and Translational Imaging, 3, 13-26.

https://doi.org/10.1007/s40336-015-0102-6

[119] Zhu, L., Ploessel, K. and Kung, H.F. (2014) PET/SPECT Imaging Agents for Neurodegerative Diseases. Chemical Society Reviews, 43, 6683-6691. https://doi.org/10.1039/C3CS60430F

[120] Furumoto, S., Okamura, N., Furukawa, K., Tashiro, M., Ishikawa, Y., Sugi, K., Tomita, N., Waragai, M., Harada, R., Tago, T., Iwata, R., Yanai, K., Arai, H. and Kudo, Y. (2013) A ${ }^{18}$ F-Labeled BF-227 Derivative as a Potential Radioligand for Imaging Dense Amyloid Plaques by Positron Emission Tomography. Molecular Imaging and Biology, 15, 497-506. https://doi.org/10.1007/s11307-012-0608-5

[121] Yousefi, B.H., von Reutern, B., Scherübl, D., Manook, A., Schwaiger, M., Grimmer, T., Henriksen, G., Förster, S., Drzezga, A. and Wester, H.-J. (2015) FIBT versus Florabetaben and PIB: A Preclinical Comparison Study with Amyloid PET in Transgenic Mice. EJNMMI Research, 5, 13 p.

[122] Ono, M., Cheng, Y., Kimura, H., Cui, M., Kagawa, S., Nishii, R. and Saji, H. (2011) Novel ${ }^{18} \mathrm{~F}$-labeled Benzofuran Derivatives with Improved Properties for Positron Emission Tomography (PET) Imaging of B-Amyloid Plaques in Alzheimer's Brains. Journal of Medicinal Chemistry, 54, 2971-2979. https://doi.org/10.1021/jm200057u

[123] Weingarten, M.D., Lockwood, A.H., Hwo, S.Y. and Kirschner, M.W. (1975) A Protein Factor Essential for Microtubule Assembly. Proceedings of the National Academy of Sciences USA, 72, 1858-1862. https://doi.org/10.1073/pnas.72.5.1858

[124] Huang, Y., Wu, Z. and Zhou, B. (2016) Behind the Curtain of Tauopathy: A Show of Multiple Players Orchestrating Tau Toxicity. Cellular and Molecular Life Sciences, 73, 1-21. https://doi.org/10.1007/s00018-015-2042-8

[125] Xia, C. and Dickerson, B.C. (2016) Tau PET: The Next Frontier in Imaging of Dementia. International Psychogeriatrics, 28, 1403-1406.

https://doi.org/10.1017/S1041610216000880

[126] Johnson, K.A., Schultz, A., Betensky, R.A., Becker, J.A., Sepulcre, J., Rentz, D., Mormino, E., Chhatwal, J., Amariglio, R., Papp, K., Marshall, G., Albers, M., Mauro, S., Pepin, L., Alverio, J., Judge, K., Philiossaint, M., Soup, T., Yokell, D., Dickerson, B., Gomez-Isla, T., Hyman, B., Vasdev, N. and Sperling, R. (2016) Tau Positron emission Tomographic Imaging in Aging and Early Alzheimer Disease. Annals of Neurology, 79, 110-119. https://doi.org/10.1002/ana.24546

[127] Klunk, W.E., Wang, Y., Huang, G.F., Debnath, M.L., Holt, D.P. and Mathis, C.A. (2001) Uncharged Thioflavin-T Derivatives Bind to Amyloid-Beta Protein with 
High Affinity and Readily Enter the Brain. Life Sciences, 69, 1471-1484. https://doi.org/10.1016/S0024-3205(01)01232-2

[128] Tago, T., Furumoto, S., Okamura, N., Harada, R., Adachi, H., Ishikawa, Y., Yanai, K., Iwata, R. and Kudo, Y. (2016) Structure-Activity Relationship of 2-Arylquinolines as PET Imaging Tracers for Tau Pathology in Alzheimer Disease. Journal of Nuclear Medicine, 57, 608-614. https://doi.org/10.2967/jnumed.115.166652

[129] Duykaerts, C., Brion, C.P., Hauw, J.J. and Falment-Durand, J. (1987) Quantitative Assessment of the Density of Neurofibrillary Tangles and Senile Plaques in Dementia of the Alzheimer Type. Comparison of Immunocytochemistry with a Specific Antibody and Bodian's Protargol Method. Acta Neuropathologica, 73, 167-170. https://doi.org/10.1007/BF00693783

[130] Hostetler, E.D., Walji, A.M., Zeng, Z., Miller, P., Bennacef, I., Salinas, C., Connolly, B., Gantert, L., Haley, H., Holahan, M., Purcell, M., Riffel, K., Lohith, T.G., Coleman, P., Soriano, A., Ogawa, A., Xu, S., Zhang, X., Joshi, E., Della Rocca, J., Hesk, D., Schenk, D.J. and Evelhoch, J.L. (2016) Preclinical Characterization of ${ }^{18} \mathrm{~F}-\mathrm{MK}-$ 6240, a Promising Positron Emission Tomography (PET) Tracer for in vivo Quantification of Human Neurofibrillary Tangles (NFTs). Journal of Nuclear Medicine, 57, 1599-1606. https://doi.org/10.2967/jnumed.115.171678

[131] Luna-Munoz, J., Chavez-Mazias, L., Garcia-Sierra, F. and Mena, R. (2007) Earliest Stages of Tau Conformational Changes are Related to the Appearance of the Sequence of Specific Phosphor-Dependent Tau Epitopes in Alzheimer's Disease. Journal of Alzheimer's Disease, 12, 365-375.

[132] Kolb, H., Attardo, G., Mintun, M., Chien, D., Elizarov, A., Conti, P., Miller, C., Joshi, A. and Skovronsky, D. (2013) First Case Report: Imaging to Autopsy Correlation for Tau Imaging with T808 (A-680). Alzheimer's \& Dementia, 9, 844-845. https://doi.org/10.1016/j.jalz.2013.08.008

[133] Chien, D.T., Szardennings, A.K., Bahri, S., Walsh, J.C., Mu, F., Xia, C., Shankle, W.R., Lerner, A.J., Su, M.-Y., Elizarov, A. and Kolb, H.C. (2014) Early Clinical PET Imaging Results with the Novel PHF-Tau Radioligand $\left[{ }^{18} \mathrm{~F}\right]-\mathrm{T} 808$. Journal of Alzheimer's Disease, 38, 171-184.

[134] Okamura, N., Furumoto, S., Fodero-Tavoletti, M.T., Mulligan, R.S., Harada, R., Yates, P., Pejoska, S., Kudo, Y., Masters, C.L., Yanai, K., Rowe, C.C. and Villemagne, V.L. (2014) Non-Invasive Assessment of Alzheimer's Disease Neurofibrillary Pathology Using ${ }^{18}$ F-THK5105 PET. Brain, 137, 1762-1771. https://doi.org/10.1093/brain/awu064

[135] Walji, A.M., Hostetler, E.D. , Selnick, H., Zeng, Z. , Miller, P., Bennacef, I., Salinas, C., Connolly, B., Gantert, L., Holahan, M., O’Malley, S., Purcell, M., Riffel, K., Li, J., Balsells, J., O’Brien, J.A., Melquist, S., Soriano, A., Zhang, X., Ogawa, A., Xu, S., Joshi, E., Della Rocca, J., Hess, F.J., Schachter, J., Hesk, D., Schenk, D., Struyk, A., Babaoglu, K., Lohith, T.G., Wang, Y., Yang, K., Fu, J., Evelhoch, J.L. and Coleman, P.J. (2016) Discovery of 6-(Fluoro- ${ }^{18} \mathrm{~F}-3-(1 \mathrm{H}-\mathrm{Pyrrolo}[2,3-\mathrm{c}]$ Pyridine-1-yl)Isoquinolin5-Amine ( $\left.\left[{ }^{18} \mathrm{~F}\right]-\mathrm{MK}-6240\right)$ : a Positron Emission Tomography (PET) Imaging Agent for Quantification of Neurofibrillary Tangles (NFTs). Journal of Medicinal Chemistry, 59, 4778-4789. https://doi.org/10.1021/acs.jmedchem.6b00166

[136] Wagner, T.T., Hou, X., Verhoest, P.R. and Villabos, A. (2010) Moving beyond Rules: The Development of a Central Nervous System Multiparameter Optimization (CNS MPO) Approach to Enable Alignment of Druglike Properties. ACS Chemical Neuroscience, 1, 435-449. https://doi.org/10.1021/cn100008c

[137] Wagner, T.T., Hou, X., Verhoest, P.R. and Villabos, A. (2016) Central Nervous System Multiparameter Optimization Desirability: Application in Drug Discovery. 
ACS Chemical Neuroscience, 7, 767-775.

https://doi.org/10.1021/acschemneuro.6b00029

[138] Spillantini, M.G., Divane, A. and Goedert, M. (1995) Assignment of Human Alpha-Synuclein (SNCA) and Beta-Synuclein (SNCB) Genes to Chromosomes 4q21 and 5q35. Genomics, 27, 379-381. https://doi.org/10.1006/geno.1995.1063

[139] Shah, M., Seibyl, J., Cartier, A., Bhatt, R. and Catafau, A.M. (2014) Molecular Imaging Insights into Neurodegeneration: Focus on Alpha Synuclein Radiotracers. Journal of Nuclear Medicine, 55, 1-4.

[140] Jellinger, K.A. (2009) A Critical Review of Current Staging $\alpha$-Synuclein Pathology in Lewy Body Disorders. $B B A, 1792,730-740$.

[141] Vernon, A.C., Ballard, C. and Modo, M. (2010) Neuroimaging for Lewy Body Disease: Is the In Vivo Molecular Imaging of Synuclein Neuropathology required and feasible? Brain Research Reviews, 65, 28-55. https://doi.org/10.1016/j.brainresrev.2010.05.006

[142] Hoehn, M. and Yahr, M. (1967) Parkinsonism: onset, progression and mortality. Neurology, 17, 427-442. https://doi.org/10.1212/WNL.17.5.427

[143] Eberling, J.L., Dave, K.D. and Frasier, M.A. (2013) $\alpha$-Synuclein Imaging: A Critical Need for Parkinson's Disease Research. Journal of Parkinson's Disease, 3, 565-567.

[144] Massano, J. and Bathia, K.P. (2012) Clinical Approach to Parkinson's Disease: Features, Diagnosis and Principles of Management. Cold Spring Harbor Perspectives in Medicine, 2, a008870, $15 \mathrm{p}$.

[145] Prusiner, S.B. (1997) Prion Disease and the BSE Crisis. Science, 278, 245-251. https://doi.org/10.1126/science.278.5336.245

[146] Kepe, V., Ghetti, B., Farlow, M.R., Bresjanac, M., Miller, K., Huang, S.-C., Wong, K.-P., Murrell, J.R., Piccardo, P., Epperson, F., Repovs, G., Smid, L.M., Petric, A., Siddarth, P., Liu, J., Sataymurthy, N., Small, G.W. and Barrio, J.R. (2010) PET of Brain Prion Protein Amyloid in Gerstmann-Sträussler-Scheinker Disease. Brain Pathology, 20, 419-430. https://doi.org/10.1111/j.1750-3639.2009.00306.x

[147] Wagner, J., Ryazanov, S, Leonov, A., Levin, J., Shi, S., Schmidt, F., Prix, C., PanMontojo, F., Bertsch, U., Mitteregger-Kretzschar, G., Geissen, M., Eiden, M., Leidel, F., Hirschberger, T., Deeg, A.A., Krauth, J., Zinth, W., Tavan, P., Pilger, J., Zweckstetter, M., Frank, T., Bähr, K., Weishaupt, J.H., Uhr, M., Urlaub, H., Teichmann, U., Samwer, M., Bötzel, K., Groschup, M., Kretzschmar, H., Griesinger, C. and Giese, A. (2013) Anle138b: A Novel Oligomer Modulator for Disease-Modifying Therapy of Neurodegenerative Diseases Such as Prion and Parkinson's Disease. Acta Neuropathologica, 125, 795-813. https://doi.org/10.1007/s00401-013-1114-9

[148] Fuchigami, T., Yamashita, Y., Kawasaki, M., Ogawa, A., Haratake, M., Atarashi, R, Sano, K., Nakagaki, T., Ubagai, K., Ono, M., Yoshida, S., Nishida, N. and Nakayama, M. (2015) Characterisation of Radioiodinated Flavonoid Derivatives for SPECT Imaging of Cerebral Prion Deposits. Nature-Scientific Reports, 5, 18440. https://doi.org/10.1038/srep18440

[149] Ghaemmaghami, S., Russo, M. and Renslo, A.R. (2014) Success and Challenges in Phenotype Based Lead Discovery for Prion Diseases. Journal of Medicinal Chemistry, 57, 6919-6929. https://doi.org/10.1021/jm5001425

[150] Cazaubon, S., Viegas, P. and Couraud, P.-O. (2007) Fonctions de la Protéine Prion PrP. Médecine/Science, 23, 741-745. https://doi.org/10.1051/medsci/20072389741

[151] Bannach, O., Birkmann, E., Reinartz, E., Jaeger, K.-E., Langeveld, J.P.M., Rohwer, R.G., Gregori, L., Terry, L.A., Willbold, D. and Riesner, D. (2012) Detection of Prion Protein Particles in Blood Plasma of Scrapie Infected Sheep, PLOS One, 7, 
e36620. https://doi.org/10.1371/journal.pone.0036620

[152] Trevitt, C.R. and Collinge, J. (2006) A Systematic Review of Prion Therapeutics in Experimental Models. Brain, 129, 2241-2265. https://doi.org/10.1093/brain/awl150

[153] Honson, N.S., Johnson, R.L., Huang, W., Inglese, J., Austin, C.P. and Kuret, J. (2007) Differentiating Alzheimer Disease-Associated Aggregates with Small Molecules. Neurobiology of Disease, 28, 251-260. https://doi.org/10.1016/j.nbd.2007.07.018

[154] Kamatari, Y.O., Hayano, Y., Yamaguchi, K.-I., Hosokawa-Muto, J. and Kuwata, K. (2013) Characterizing Antiprion Compounds Based on their Binding Properties to Prion Proteins: Implications as Medical Chaperons. Protein Science, 22, 22-34. https://doi.org/10.1002/pro.2180

[155] Matsumura, K. On, M., Yoshimura, M., Kimura, H., Watanabe, H., Okamoto, Y., Ihara, M., Takahashi, R. and Sagi, H. (2013) Synthesis and Biological Evaluation of Novel Styryl Benzimidazole Derivatives as Probes for Imaging of Neurofibrillary Tangles in Alzheimer's Disease. Bioorganic \& Medicinal Chemistry, 21, 3356-3362. https://doi.org/10.1016/j.bmc.2013.02.054

[156] May, B.C.H., Fafarman, A.T., Hong, S.B., Rogers, M., Deady, L.W., Prusiner, S.B. and Cohen, F.E. (2003) Potent Inhibition of Scrapie Prion Replication in Cultured Cells by Bis-Acridines. PNAS, 100, 3416-3421. https://doi.org/10.1073/pnas.2627988100

[157] Bolognesi, M.L., Tran, H.N.A., Staderini, M., Monaco, A., Lopez-Cobenas, A., Bongarzone, S., Biarnes, X., Lopez-Alvarado, P., Cabezas, N., Caramelli, M., Carloni, P., Menendez, J.C. and Legname, G. (2010) Discovery of a Class of Diketopiperazines as Antiprion Compounds. ChemMedChem, 5, 1324-1334.

https://doi.org/10.1002/cmdc.201000133

[158] Bosque, P. and Prusiner, S.B. (2000) Cultured Sublines Highly Susceptible to Prion Infection. Journal of Virology, 74, 4377-4386. https://doi.org/10.1128/JVI.74.9.4377-4386.2000

[159] Bongarzone, S., Tran, H.N.A., Cavalli, A., Roberti, M., Carloni, P., Legname, G. and Bolognesi, M.L. (2010) Parallel Synthesis, Evaluation, and Preliminary Structure-Activity Relationship of 2,5-Diamino-1,4-Benzoquinones as a Novel Class of Bivalent Anti-Prion Compound. Journal of Medicinal Chemistry, 53, 8197-8201. https://doi.org/10.1021/jm100882t

[160] Mueller-Gaertner, H.W., Links, J.M., Prince, J.L., Bryan, R.N., McVeigh, E., Leal, J.P., Davazikos, Ch. and Frost, J. (1992) Measurement of Radiotracer Concentration in Brain Gray Matter Using Positron Emission Tomography: MRI-Based Correction for Partial Volume Effects. Journal of Cerebral Blood Flow \& Metabolism, 12, 571-583. https://doi.org/10.1038/jcbfm.1992.81

[161] Box, K., Comer, J. and Huque, F. (2007) Correlations between PAMPA Permeability and $\log$ P. In: Testa, B., Krämer, S.D., Wunderli-Allenspach, H. and Folkers, G., Eds., Pharmacokinetic Profiling in Drug Research-Biological, Physicochemical, and Computational Strategies, 243-257.

[162] Bongarzone, S. and Bolognesi, M.L. (2011) The Concept of Privileged Structures in Rational Drug Design: Focus on Acridine and Quinolone Scaffolds in Neurodegenerative and Protozoan Diseases. Expert Opinion on Drug Discovery, 6, 251-268. https://doi.org/10.1517/17460441.2011.550914

[163] Cummings, J.L., Morstorf, T. and Zhon, K. (2014) Alzheimer's Disease Drug-Development Pipeline: Few Candidates, Frequent Failure. Alzheimer's Research Therapy, 6, 37, $7 \mathrm{p}$.

[164] Yeo, J.M., Waddell, B., Khan, Z. and Pal, S. (2015) A Systematic and Metaanalysis of 
${ }^{18} \mathrm{~F}$-Labelled Amyloid Imaging in Alzheimer's Disease. Alzheimer's Dementia, Assessment \& Disease Monitoring, 1, 5-13. https://doi.org/10.1016/j.dadm.2014.11.004

\section{Abbreviations}

AD: Alzheimer's Disease

Aß: Amyloid- $B$

APP: Amyloid precursor protein

Bbb: Blood brain barrier

CBD: Corticobasal degeneration

FTLD: Fronto temporal lobe dementia

LBD: Lewy body disease

MAPS: Microtubule-associated proteins

MAPT: Microtubule associated tau protein

MCI: Mild cognitive impairment

MPTP: 1-Methyl-4-phenyl-1,2,3,6-tetrahydropyridin

MSA: Multiple system atrophy

NFT: Neurofibrillary tangles

PC12Rat: pheochromocytoma-derived cell line

Prion: Proteinaceous infectious particle

$\operatorname{PrP}^{c}$ : Constitutive isoform of prion protein

$\mathrm{PrP}^{\text {sc: }}$ Amyloidogenic isoform of prion protein

PSP: Progressive supranuclear palsy

RIP: Regulated intramembrane proteolysis

ScGT1: Mouse hypothalamic cell line, subline GT1

ScN2A: C-1300 mouse neuroblastoma cell line; neuro-2A subline (N2A)

SUV: Standard uptake value

TLR: Toll-like receptor 
Submit or recommend next manuscript to SCIRP and we will provide best service for you:

Accepting pre-submission inquiries through Email, Facebook, LinkedIn, Twitter, etc. A wide selection of journals (inclusive of 9 subjects, more than 200 journals)

Providing 24-hour high-quality service

User-friendly online submission system

Fair and swift peer-review system

Efficient typesetting and proofreading procedure

Display of the result of downloads and visits, as well as the number of cited articles Maximum dissemination of your research work

Submit your manuscript at: http://papersubmission.scirp.org/

Or contact wijns@scirp.org 